

CrossMark $\leftarrow$ click for updates

Cite this: Dalton Trans., 2016, 45 15859

Received 5th May 2016,

Accepted 2nd June 2016

DOI: 10.1039/c6dt01760f

www.rsc.org/dalton

\section{Versatile bonding and coordination modes of ditriazolylidene ligands in rhodium(III) and iridium(III) complexes $\dagger$}

\begin{abstract}
Kevin Farrell, ${ }^{a}$ Helge Müller-Bunz ${ }^{a}$ and Martin Albrecht*a,b
Metalation of novel ditriazolium salts containing a trimethylene $\left(-\mathrm{CH}_{2} \mathrm{CH}_{2} \mathrm{CH}_{2}{ }^{-}\right)$or dimethylether linker $\left(-\mathrm{CH}_{2} \mathrm{OCH}_{2}-\right)$ was probed with different rhodium(III) and iridium(III) precursors. When using $\left[\mathrm{MCp}^{*} \mathrm{Cl}_{2}\right]_{2}, \mathrm{a}$ transmetalation protocol via a triazolylidene silver intermediate was effective, while base-assisted metalation with $\mathrm{MCl}_{3}$ via sequential deprotonation of the triazolium salt with $\mathrm{KOtBu}$ and addition of the metal precursor afforded homoleptic complexes. The $N$-substituent on the triazole heterocycle directed the metalation process and led to $\mathrm{C}_{\mathrm{trz}}, \mathrm{C}_{\mathrm{trz}}, \mathrm{C}_{\mathrm{Ph}}$-tridentate chelating ditriazolylidene complexes for $\mathrm{N}$-phenyl substituents. With ethyl substituents, only $\mathrm{C}_{\mathrm{trz}} \mathrm{C}_{\mathrm{trz}}$-bidentate complexes were formed, while metalation with mesityl substituents was unsuccessful, presumably due to steric constraints. Through modification of the reaction conditions for the metalation step, an intermediate species was isolated that contains a $\mathrm{C}_{\text {trz }}$, $\mathrm{C}_{\mathrm{Ph}}$-bidentate chelate en route to the formation of the tridentate ligand system. Accordingly, $\mathrm{C}_{\text {phenyl }}-\mathrm{H}$ bond activation occurs prior to formation of the second metal-triazolylidene bond. Stability studies with a $\mathrm{C}_{\mathrm{trz}}, \mathrm{C}_{\mathrm{trz}}, \mathrm{C}_{\mathrm{Ph}}$-tridentate chelating ditriazolylidene iridium complex towards $\mathrm{DCl}$ showed deuterium incorporation at both $\mathrm{N}$-phenyl groups and indicate that $\mathrm{C}_{\text {phenyl }}-\mathrm{H}$ bond activation is reversible while the $\mathrm{C}_{\mathrm{trz}}-\mathrm{Ir}$ bond is robust. The flexible linker between the two triazolylidene donor sites provides access to both facial and meridional coordination modes.
\end{abstract}

\section{Introduction}

The discovery of N-heterocyclic carbenes (NHCs) as ligands for transition metals has fundamentally transformed organometallic chemistry ${ }^{1}$ and has spurred in particular ${ }^{2}$ the development of new generations of homogeneous catalysts. ${ }^{3}$ As a consequence of this success, the NHC theme has been varied in all dimensions, including the development of chiral systems, ${ }^{4}$ of non-cyclic analogues, ${ }^{5}$ of carbenes with reduced heteroatom stabilization ${ }^{6}$ and of course the combination of different privileged ligands together with carbenes. ${ }^{7} 1,2,3$-Triazolylidenes are a subclass of NHCs that have received considerable attention over the last few years, ${ }^{8}$ and which offer vast opportunities for catalysis ${ }^{9}$ and beyond. ${ }^{10}$ Their mesoionic character ${ }^{11}$ and strong $\sigma$-donor ability are attractive features for

\footnotetext{
${ }^{a}$ School of Chemistry and Chemical Biology, University College Dublin, Belfield, Dublin 4, Ireland. E-mail: martin.albrecht@dcb.unibe.ch

${ }^{b}$ Department of Chemistry \& Biochemistry, University of Bern, Freiestrasse 3 , 3012 Bern, Switzerland

$\dagger$ Electronic supplementary information (ESI) available: NMR spectra of 5a and 14, and details on crystal structure determinations. CCDC 1477827-1477830. For ESI and crystallographic data in CIF or other electronic format see DOI: 10.1039/ c6dt01760f
}

tailoring the properties of the coordinated metal center. ${ }^{12}$ Moreover, these heterocycles are accessible via copper(I) catalyzed 'click' $[2+3]$ cycloaddition of an alkyne and azide (CuAAC) ${ }^{13}$ a reaction that stands out for its versatility and its exceptionally broad functional group tolerance. ${ }^{14}$ As a consequence, various donor-functionalized triazolylidene complexes with a wide range of chelating groups have been developed. ${ }^{8}$ Surprisingly however, triazolylidene-based chelating dicarbenes have not been studied extensively, despite the kinetic and thermodynamic stability imparted by chelation. To date, two approaches for linking 1,2,3-triazolium salts via either the triazole $\mathrm{C} 4$ or $\mathrm{N} 3$ position were reported, involving a di-alkyne and a di-azide precursor, respectively. For example, C4-linked ditriazolium salts with rigid aryl-bridges have been metalated with rhodium, ${ }^{15}$ ruthenium, ${ }^{16}$ nickel, ${ }^{17}$ and palladium, ${ }^{18}$ leading to bimetallic systems (Fig. 1, A) or CNC-type pincer complexes (B). Directly linked ditriazolylidenes were coordinated to rhodium, ${ }^{19}$ iridium, and ruthenium $(\mathbf{C}){ }^{20}$ Similarly, alkyl- or aryl-linkages via N3 have led to bimetallic complexes of ruthenium ${ }^{21}$ and iridium ${ }^{22}$ in which the ligand adopts a bridging rather than chelating binding mode (D, E).

Trimethylene-linked dicarbene ligands similar to those present in complex E, yet comprised of imidazolylidenes rather than triazolylidene heterocycles, induced alkyl $\mathrm{C}-\mathrm{H}$ 




A





B

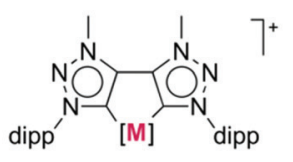

$[\mathrm{M}]=\mathrm{Rh}(\mathrm{CO})_{2}, \operatorname{IrCl}\left(\mathrm{Cp}^{*}\right)$, $\mathrm{Ru}(p$-cym $) \mathrm{Cl}$

C

Fig. 1 Known ditriazolylidene complexes including C, C'-linked ditriazolylidene ligands (A, B, C) and N,N'-linked ditriazolylidene scaffolds (D, E).

bond activation of the central methylene unit by rhodium or ruthenium, thus forming a tridentate dicarbene species. ${ }^{23}$ The $\mathrm{C}_{\text {alkyl }}-\mathrm{H}$ bond activation was significantly faster when the imidazolylidene is bound to rhodium via $\mathrm{C} 4$ as a mesoionic carbene rather than in the normal C2-bonding mode. ${ }^{23 a}$ Based on these considerations, we were interested to investigate the reactivity of analogous di-1,2,3-triazolylidene systems that are mesoionic as well. In addition, heteroatoms can easily be introduced into the triazolylidene linker, which may provide further reactivity patterns. Here, we report the synthesis of chelating ditriazolylidene rhodium(III) and iridium(III) complexes which contain flexible C, $\mathrm{C}^{\prime}$-linked ditriazolylidenes. The flexibility accommodates both facial and meridional coordination modes and the peripheral substituents at the heterocycle dictate the coordination mode of the triazolylidenes, thus demonstrating strong reactivity control by ligand design.

\section{Results and discussion}

\section{Synthesis of the ligand precursors}

The C,C'-linked ditriazoles $\mathbf{3}$ and $\mathbf{4}$ were synthesised in good to excellent yields (71-95\%) via the 'click' cycloaddition of the commercially available diynes $\mathbf{1}$ and $\mathbf{2}$, and the corresponding azide, (Scheme 1). The alkyl linker was identified by a characteristic triplet for the $\mathrm{C}_{\mathrm{trz}} \mathrm{CH}_{2}$ group and a quintet for the central methylene unit. For example for compound 3a, these multiplets appeared at $\delta_{\mathrm{H}} 2.67$ and 1.94 in the ${ }^{1} \mathrm{H}$ NMR spectrum respectively, while the ether linker showed as a singlet, e.g. at $\delta_{\mathrm{H}} 4.71$ for $4 \mathrm{a}$. The versatility of the 'click' reaction allows for the facile variation of the N-bound substituent in the ligand precursor. This versatility is beneficial for the steric and electronic tailoring of the ligand environment when bound to the metal which is particularly useful for bond activation reactions. Alkylation of the ditriazoles with methyl iodide gave the ditriazolium salts 5(I) and 6(I) in good yields (Scheme 1). After quaternization, the ${ }^{1} \mathrm{H}$ NMR signal of the heterocyclic proton shifted downfield by almost $1 \mathrm{ppm}$. For example the $\mathrm{C}_{\mathrm{trz}}-\mathrm{H}$ in $\mathbf{5 a}(\mathrm{I})$ appeared as a singlet at $\delta_{\mathrm{H}} 8.87$ compared to $\delta_{\mathrm{H}} 7.54 \mathrm{ppm}$ in the precursor 3a. In addition, a new signal emerged in the ${ }^{1} \mathrm{H}$ and ${ }^{13} \mathrm{C}$ NMR spectrum for the $\mathrm{N}$-bound methyl group $\left(\delta_{\mathrm{H}} 4.20, \delta_{\mathrm{C}} 38.2\right.$ for $\left.5 \mathrm{a}(\mathrm{I})\right)$. Anion substitution with $\mathrm{AgBF}_{4}$ afforded the corresponding ditriazolium salts $\mathbf{5}\left(\mathbf{B F}_{4}\right)$ and $\mathbf{6}\left(\mathbf{B F}_{\mathbf{4}}\right)$. Successful anion exchange was indicated by a diagnostic $\sim 0.5 \mathrm{ppm}$ upfield shift of the $\mathrm{C}_{\mathrm{trz}}-\mathrm{H}$ resonance in the ${ }^{1} \mathrm{H}$ NMR spectrum, presumably due to less pronounced $\mathrm{X} \cdots \mathrm{H}$ hydrogen bonding. ${ }^{24}$

\section{Metalation of ditriazolium salts with $\left[\mathrm{MCp}^{*} \mathrm{Cl}_{2}\right]_{2}$}

In an initial set of experiments, the well-established transmetalation procedure involving the formation of a triazolylidene silver(I) intermediate was utilised for the formation of triazolylidene rhodium(III) and iridium(III) complexes. ${ }^{8 d, 25}$ Successful

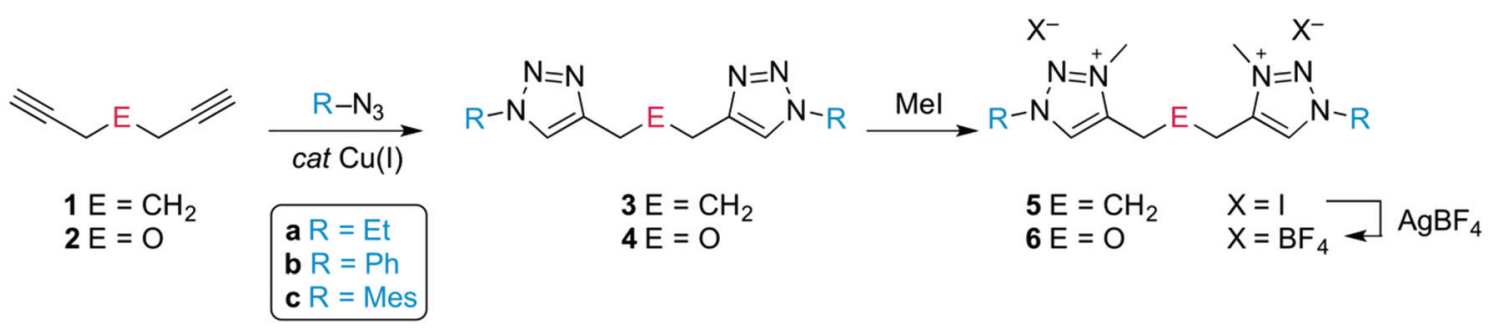

Scheme 1 Ligand precursor synthesis via 'click' cycloaddition and alkylation. 
metalation of the triazolium salts using $\mathrm{Ag}_{2} \mathrm{O}$ in the presence of $\mathrm{KCl}$ was surmised by the disappearance of the ${ }^{1} \mathrm{H}$ NMR signal of the $\mathrm{C}_{\mathrm{trz}}-\mathrm{H}$ unit, and by the appearance of a mass signal which is in agreement with the $[\mathrm{Ag}(\text { ditriazolylidene })]^{+}$ fragment. The ${ }^{1} \mathrm{H}$ NMR spectrum of the triazolylidene silver complexes showed a symmetric linker which suggests a dimeric $\left[\mathrm{Ag}_{2}\left(\operatorname{trz}^{\wedge} \mathrm{E}^{\wedge} \mathrm{trz}\right)_{2}\right]^{2+}$ species rather than a chelating $\left[\operatorname{Ag}\left(\operatorname{trz}^{\wedge} \mathrm{E}^{\wedge} \operatorname{trz}\right)\right]^{+}$monomer, in agreement with results by Crudden and co-workers. ${ }^{15}$ The formation of the silver triazolylidene proceeded at elevated temperatures when using the $N$-ethyl triazolium salts (refluxing $\mathrm{MeCN}$ ), while $N$-aryl triazolium salts reacted under milder conditions and provided the desired triazolylidene silver intermediate at room temperature. Triazolylidene silver complexes were also formed in the absence of a chloride additive, though significant decomposition was observed and yields were typically much lower, presumably because the triazolylidene silver unit is less stabilized by tetrafluoroborate as compared to chlorides. ${ }^{9 e, 21,26}$ Likewise, the triazolylidene silver intermediates were accessible also from the triazolium iodide salts 5(I), but in agreement with previous reports, ${ }^{27}$ the reaction was generally less clean than when starting from $\mathbf{5}\left(\mathbf{B F}_{\mathbf{4}}\right)$. Carbene silver complexes are known to exist in an equilibrium between ionic species of type $\left[\mathrm{Ag}(\text { carbene })_{2}\right] \mathrm{AgX}_{2}$ and the neutral isomer $[\mathrm{AgX}($ carbene $\left.)]\right]^{28}$ which is delicately dependent on conditions and will lead to oligo- or polymeric systems with ditopic carbenes as used here. Due to this fluxionality, no attempts have been made to structurally characterize these intermediates.

The triazolylidene silver complexes were used without further purification for transmetalation with $\left[\mathrm{MCp}^{*} \mathrm{Cl}_{2}\right]_{2}(\mathrm{M}=$ $\mathrm{Rh}, \mathrm{Ir}$ ), and afforded the chelating ditriazolylidene complexes 7-10 (Scheme 2). All complexes were air- and moisture stable and were isolated by standard column chromatography as red $(7,8)$ or orange solids $(\mathbf{9}, \mathbf{1 0})$ that are moderately soluble in $\mathrm{CH}_{2} \mathrm{Cl}_{2}$ and readily soluble in MeCN.

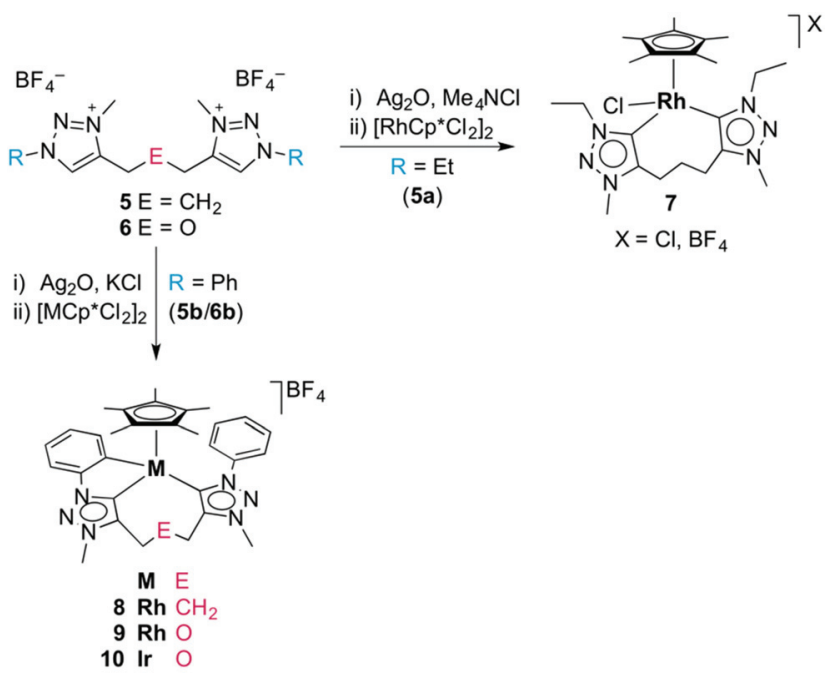

Scheme 2 Formation of complexes 7-10 by transmetalation via a silver carbene intermediate.
Chelation in complex 7 was indicated by the presence of symmetry-related triazolylidene units and the pertinent $5: 2$ integral ratio of the resonances due to the $\mathrm{Cp}^{*}$ protons and the $\mathrm{N}-\mathrm{CH}_{3}$ unit. The carbenic ${ }^{13} \mathrm{C} \mathrm{NMR}$ resonance is deshielded and appears at $\delta_{\mathrm{C}} \mathbf{1 5 4 . 4}$ as a doublet due to characteristic ${ }^{103} \mathrm{Rh}$ coupling $\left({ }^{1} J_{\mathrm{CRh}}=50.3 \mathrm{~Hz}\right)$. Furthermore, chelation led to diastereotopic methylene protons in the ethyl wingtip group as indicated by the two doublet of quartets at $\delta_{\mathrm{H}} 4.81$ and $4.42\left({ }^{2} J_{\mathrm{HH}}=12.9 \mathrm{~Hz},{ }^{3} J_{\mathrm{HH}}=7.2 \mathrm{~Hz}\right)$. Similarly, the triazolylidene bound $\mathrm{CH}_{2}$ group of the trimethylene linker appeared as two doublets of doublets of doublets $\left({ }^{2} J_{\mathrm{HH}}=14.9 \mathrm{~Hz},{ }^{3} J_{\mathrm{HH}}=8.6 \mathrm{~Hz},{ }^{3} J_{\mathrm{HH}}=4.6 \mathrm{~Hz}\right)$. Of note, a multiplet in the 1.88-1.69 ppm range integrated for two protons and was attributed to the central $\mathrm{CH}_{2}$ group of the linker, thus suggesting that the linker has not been affected. This reactivity differs from that of related rhodium(III) complexes containing mesoionic diimidazolylidene ligands, in which $\mathrm{C}-\mathrm{H}$ bond activation of the linker methylene group is spontaneous. $^{23}$ X-ray crystallographic analysis of complex 7 unambiguously confirmed the ligand bonding mode surmised from spectroscopic studies (Fig. 2). The complex cation shows the typical three-legged piano-stool geometry with two triazolylidenes and one chloride ligand site forming the 'legs'. The carbene bite angle is relatively wide, $\mathrm{C}_{\mathrm{trz}}-\mathrm{Rh}-$ $\left.\mathrm{C}_{\mathrm{trz}}=91.21(9)\right)^{\circ} .{ }^{29}$ While the triazolylidene units are symmetrical in solution, the $\mathrm{C}_{\mathrm{trz}}-\mathrm{Rh}$ bond lengths of complex 7 differ considerably in the solid state (C1-Rh 2.026(2) $\AA$, C11-Rh 2.082(2) $\AA$ ). This difference may be a direct consequence of the different orientation of the triazolylidene heterocycles in the solid state with respect to the rhodium coordination geometry, e.g. the $\mathrm{Cl}-\mathrm{Rh}-\mathrm{C}-\mathrm{N}$ dihedral angle is $48.4(2)^{\circ}$ for the heterocycle containing $\mathrm{C} 1$ and $71.1(2)^{\circ}$ for the heterocycle containing C7. In solution, these distinct arrangements average out as indicated by the symmetric NMR pattern observed for this complex.



Fig. 2 ORTEP representation of the complex cation complex 7 (50\% probability ellipsoids, hydrogens omitted for clarity). Selected bond lengths: Rh-C1 2.026(2) $\AA, \mathrm{Rh}-\mathrm{C} 7$ 2.082(2) $\AA$, Rh-Cl 2.410(4) $\AA$, Rh$\mathrm{Cp}_{\text {centroid }}$ 1.862(4) $\AA$; selected bond angles: C1-Rh-C7 91.21(9) ${ }^{\circ}$; C1$\mathrm{Rh}-\mathrm{Cl} 96.16(6)^{\circ}, \mathrm{C} 7-\mathrm{Rh}-\mathrm{Cl} 84.74(7)^{\circ}$. 
It is worth noting that the analogous rhodation of the ether-linked ditriazolium salt $\mathbf{6 a}\left(\mathbf{B F}_{4}\right)$ has failed in our hands so far. Formation of the carbene silver intermediate was confirmed by the pertinent NMR and MS data, though substantial amounts of impurities were observed. Possibly, the ether linkage interacts with the silver ion and destabilizes this intermediate under the applied reaction conditions.

The presence of phenyl substituents at the triazole heterocycle altered the outcome of the reaction and induced cyclometalation through activation of one of the ortho $\mathrm{C}_{\text {phenyl }}-\mathrm{H}$ bonds in $\mathbf{5 b}$ and $\mathbf{6 b}$ to yield complexes 8-10 containing a C,C,C-tridentate coordinated ditriazolylidene ligand (Scheme 2). Similar C-H bond activation was observed previously in monotriazolylidene complexes containing N-bound phenyl-substituents. ${ }^{30}$ Apparently the $\mathrm{C}_{\text {phenyl }}-\mathrm{H}$ bond activation process is preferred over heteroatom coordination and is spontaneous even at $-30^{\circ} \mathrm{C}$ both with rhodium and iridium precursors. No trace of a coordinated triazolylidene with a non-cyclometalated phenyl group was observed by NMR spectroscopy. Cyclometalation was indicated by the ligand desymmetrization as revealed by the presence of seven distinct phenyl proton resonances in the low-field section of the ${ }^{1} \mathrm{H}$ NMR spectrum integrating for 9 protons. While one set features the typical $2: 2: 1$ pattern of a pristine phenyl group, the second set is constituted of four signals that are characteristic for a ortho disubstituted phenylene system, with two doublets and two multiplets that are correlated and integrating for one proton each. Ligand desymmetrization was also apparent from the two distinct singlets due to inequivalent $\mathrm{NCH}_{3}$ groups. Similarly, the $\mathrm{OCH}_{2}$ groups of the linker of complexes $\mathbf{9}$ and $\mathbf{1 0}$ were inequivalent and appeared as two sets of $\mathrm{AB}$ doublets with characteristic ${ }^{2} J_{\mathrm{HH}}$ coupling constants around $15 \mathrm{~Hz}$. Three low-field ${ }^{13} \mathrm{C}$ signals were observed in the ${ }^{13} \mathrm{C}\left\{{ }^{1} \mathrm{H}\right\}$ NMR spectrum for all three complexes 8-10 and were attributed to the two metalbound carbenic carbons and the phenyl carbon. For example, the rhodium complex 8 showed three doublets at $\delta_{\mathrm{C}} 164.2$ $\left(\mathrm{C}_{\mathrm{trz}},{ }^{1} J_{\mathrm{CRh}}=47.0 \mathrm{~Hz}\right), 159.5\left(\mathrm{C}_{\mathrm{phenyl}},{ }^{1} J_{\mathrm{CRh}}=36.2 \mathrm{~Hz}\right)$ and 158.2 $\left(\mathrm{C}_{\mathrm{trz}},{ }_{\mathrm{CRh}}=50.3 \mathrm{~Hz}\right)$. The smaller ${ }^{1} J_{\mathrm{CRh}}$ coupling constant was attributed to the $\mathrm{Rh}-\mathrm{C}_{\text {phenyl }}$ bond, ${ }^{30 b_{f} f}$ and the larger coupling constants to Rh- $\mathrm{C}_{\text {trz }}$ interactions. The larger coupling constant at $\delta_{\mathrm{C}} 158.2$ is identical to the coupling observed in complex 7 $\left({ }^{1} J_{\mathrm{CRh}}=50.3 \mathrm{~Hz}\right.$, vide supra $)$, therefore suggesting this resonance to be due to the triazolylidene unit that contains the noncyclometalated phenyl substituent. Accordingly, the resonance at $\delta_{\mathrm{C}} 164.2$ with a slightly smaller coupling constant was tentatively attributed to the carbenic carbon of the triazolylidene containing the metal-bound phenylene fragment.

Further evidence for the tridentate bonding of the ligand was obtained by single crystal X-ray diffraction of complexes 8 and 9 (Fig. 3, Table 1). Both structures are identical within errors and unambiguously reveal a $\mathrm{Rh}-\mathrm{C}_{\text {phenyl }}$ bond in addition to the dicarbene bonding. All three $\mathrm{Rh}-\mathrm{C}$ bond lengths are within expectation and in the 2.00-2.06 ̊ range. The average carbene bite angle is $81.5(2)^{\circ}$ and thus considerably more acute than in the bidentate carbene complex $7\left(\mathrm{C}_{\mathrm{trz}}{ }^{-}\right.$ $\left.\mathrm{Rh}-\mathrm{C}_{\mathrm{trz}}=91.21(9)^{\circ}\right)$.
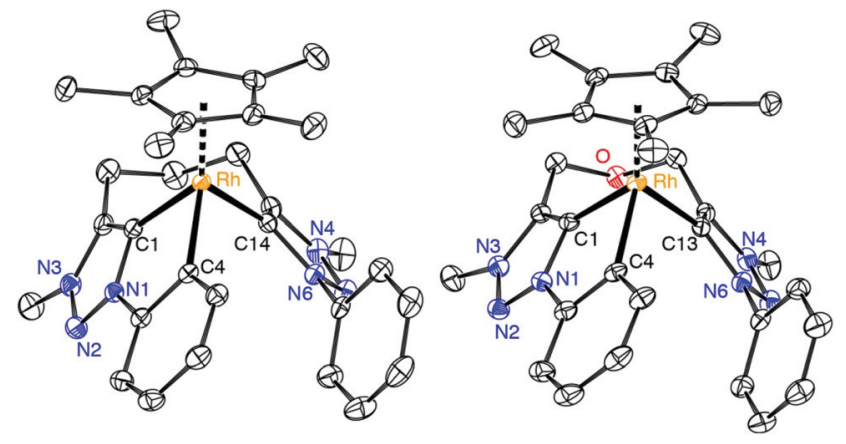

Fig. 3 ORTEP representation of the complex cations of 8 (a), 9 (50\% probability ellipsoids, hydrogen atoms omitted for clarity).

Table 1 Selected bond lengths $(\AA \AA)$ and angles $\left(^{\circ}\right)$ for 8 and 9

\begin{tabular}{lll}
\hline & $\mathbf{8}$ & $\mathbf{9}$ \\
\hline $\mathrm{Rh}-\mathrm{C} 1$ & $2.026(12)$ & $2.004(2)$ \\
$\mathrm{Rh}-\mathrm{C} 13 / 14$ & $2.033(12)$ & $2.054(2)$ \\
$\mathrm{Rh}-\mathrm{C} 4$ & $2.050(12)$ & $2.057(2)$ \\
$\mathrm{Rh}-\mathrm{Cp}$ centroid & $1.889(1)$ & $1.899(2)$ \\
$\mathrm{C} 1-\mathrm{Rh}-\mathrm{C} 13 / 14$ & $81.62(5)$ & $81.43(8)$ \\
$\mathrm{C} 1-\mathrm{Rh}-\mathrm{C} 4$ & $78.97(5)$ & $78.86(9)$ \\
$\mathrm{C} 4-\mathrm{Rh}-\mathrm{C} 13 / 14$ & $92.85(5)$ & $92.92(8)$
\end{tabular}

Minor by-products were observed in the crude reaction mixture of the iridium complex 10 by ${ }^{1} \mathrm{H}$ NMR spectroscopy, which revealed the characteristic pattern of a cyclometalated phenyl group. Separation by column chromatography yielded traces of the bimetallic complex 11 (Fig. 4), in which both $N$-phenyl groups are ortho-metalated to different iridium centers. The ${ }^{1} \mathrm{H}$ NMR spectrum indicated symmetry-related triazolylidene and phenyl groups, and a diagnostic $2: 1 \mathrm{Cp}^{*} /$ ligand ratio. The bridging coordination mode was further supported by the single $\mathrm{AB}$ doublet $\left({ }^{2} \mathrm{~J}_{\mathrm{HH}}=12.6 \mathrm{~Hz}\right)$ for the $\mathrm{OCH}_{2}$ group, while the chelating complex 10 featured two $\mathrm{AB}$ doublets because of the lack of symmetry in the ligand. The carbonic resonance appeared at $\delta_{\mathrm{C}} 153.2$ in the ${ }^{13} \mathrm{C}\left\{{ }^{1} \mathrm{H}\right\}$ NMR spectrum. A high field resonance at $\delta_{\mathrm{C}} 114.0$, attributed to the $\mathrm{C}_{\text {phenyl }}-\mathrm{H}$ nucleus ortho to the $\mathrm{N}_{\text {trz }}$ (i.e. formally $\mathrm{C} 3$ of the phenylene unit), is diagnostic for cyclometalation. In the chelate complexes 8-10, this nucleus appears at essentially the same frequency (approximately $113.5 \mathrm{ppm}$ ). While NMR studies strongly support the bridging coordination mode of the bis(triazolylidene) ligand, we were unable to purify this


Fig. 4 Complexes 11 and 12 as minor products from transmetalation reaction. 
complex sufficiently for elemental analysis or X-ray diffraction analysis, which has prevented the unambiguous identification of the spectator ligand so far. Attempts to selectively form the bimetallic complex by adding the preformed triazolylidene silver complex dropwise to a concentrated solution of $\left[\operatorname{IrCp}^{*} \mathrm{Cl}_{2}\right]_{2}$ cleanly produced complex 10 together with unreacted $\left[\operatorname{IrCp}^{*} \mathrm{Cl}_{2}\right]_{2}$, yet no bimetallic species was observed.

When reacting $\mathbf{6 b}\left(\mathbf{B F}_{4}\right), \quad \mathrm{Ag}_{2} \mathrm{O}$, and $\left[\mathrm{IrCp}^{*} \mathrm{Cl}_{2}\right]_{2}$ simultaneously rather than sequentially (vide supra), a yellow mixture was obtained. NMR analysis of this crude mixture identified four distinct species including complexes $\mathbf{1 0}$ and $\mathbf{1 1}$ and two species, which were isolated by successive precipitation. Spectroscopic analysis indicated a mixture of two strongly related species in approximate $2: 1$ molar ratio and with a general bonding pattern that is in agreement with the one depicted for complex 12 (Fig. 4). The two species were tentatively assigned as the chloro and the solvento analogues $(\mathrm{X}=$ $\mathrm{Cl}, \mathrm{NCMe})$. Both species feature a low-field resonance $\left(\delta_{\mathrm{H}} 9.10\right.$ and 8.87) for the triazolium proton and two $\mathrm{AB}$ systems for the $\mathrm{OCH}_{2}$ groups, indicating desymmetrization of the linker. ${ }^{31}$ Likewise, the $\mathrm{NCH}_{3}$ groups appeared as distinct singlets. The ${ }^{13} \mathrm{C}\left\{{ }^{1} \mathrm{H}\right\}$ NMR spectrum of this mixture showed two $\mathrm{C}_{\mathrm{trz}}-\mathrm{Ir}$ signals at $\delta_{\mathrm{C}} 153.4$ or 146.6 and two $\mathrm{C}_{\mathrm{trz}}-\mathrm{H}$ carbon resonances $\left(\delta_{\mathrm{C}} 128.9\right.$ or 128.8$)$. Heteronuclear multiple bond correlation (HMBC) spectroscopy identified for each of the two species an interaction of one $\mathrm{OCH}_{2} \mathrm{AB}$ set with the iridium-bound triazolylidene unit, and a correlation of the second $\mathrm{OCH}_{2}$ resonances with the triazolium $\mathrm{C}_{\mathrm{trz}}-\mathrm{H}$ unit. While the aromatic region in the ${ }^{1} \mathrm{H}$ NMR spectrum was inconclusive due to significant signal overlap, two high field aryl ${ }^{13} \mathrm{C}$ NMR resonances at $\delta_{\mathrm{C}}$ 114.7 and 114.0 are in agreement with cyclometalation of the phenyl ring and $\mathrm{C}_{\text {trz }}, \mathrm{C}_{\text {phenyl }}$-bidentate coordination of the ligand. In addition, two resonances at $\delta_{\mathrm{C}} 138.6$ and 138.5 have been attributed to the iridium-bound $\mathrm{C}_{\text {phenyl }}$ nucleus $\left(c f . \delta_{\mathrm{C}}\right.$ 139.5 in 10). Mass spectrometry was consistent with the NMR data and showed a $\mathrm{m} / \mathrm{z}$ signal at $344 \mathrm{amu}$, in line with formation of complex 12 (expected $\mathrm{m} / z$ for $\left[\mathrm{C}_{30} \mathrm{H}_{35} \mathrm{IrN}_{6} \mathrm{O}\right]^{2+}$ is $344.12 \mathrm{amu})$. The isolation of $\mathrm{C}_{\text {trz }}, \mathrm{C}_{\text {phenyl }}$-bidentate ligated complex 12 in combination with the absence of any $\mathrm{C}_{\mathrm{trz}}, \mathrm{C}_{\mathrm{trz}}{ }^{-}$ bidentately bound iridium complex akin to complex 7 strongly suggests that $\mathrm{C}_{\text {phenyl }}-\mathrm{H}$ bond activation is spontaneous. Formation of complex $\mathbf{1 2}$ may be a consequence of incomplete triazolylidene silver formation or due to partial hydrolysis of the semi-transmetalated intermediate prior to chelation of the second carbene unit.

The $\mathrm{C}_{\text {phenyl }} \mathrm{H}$ bond activation is reversible. Under acidic conditions (20 equiv. $\mathrm{DCl}$ in $\mathrm{CD}_{3} \mathrm{CN}$ ) and at room temperature, the iridium complex 10 incorporated approximately 7\% deuterium at the ortho positions of both the cyclometalated and the non-cyclometalated phenyl group $(24 \mathrm{~h})$. Heating accelerates this isotope exchange, reaching $27 \%$ deuterium incorporation at $50{ }^{\circ} \mathrm{C}(16 \mathrm{~h})$ and up to $60 \%$ when heated to $80{ }^{\circ} \mathrm{C}$ for $10 \mathrm{~h}$. Gradual decomposition to the triazolium salt was observed under these relatively harsh conditions, and the reaction was therefore aborted after $10 \mathrm{~h}$, presumambly due to hydrolysis of the $\mathrm{Rh}-\mathrm{C}_{\mathrm{trz}}$ bond. Deuteration of the ortho positions of both phenyl rings occur initially to the same extent (e.g. $27 \%$ D-incorporation in the cyclometalated phenyl group vs. $26 \%$ $\mathrm{H} / \mathrm{D}$ exchange in the non-cyclometalated residue after $16 \mathrm{~h}$ at $\left.50{ }^{\circ} \mathrm{C}\right)$. At higher conversion, the incorporation in the noncyclometallated ring is slightly higher $(68 \%$ vs. $54 \%$ in the cyclometalated phenyl group). The isotope exchange on both phenyl groups indicates that cyclometalation is reversible, involving a bidentate ditriazolylidene species with two free phenyl groups as a potential transient intermediate which undergoes cyclometalation of either of the two phenyl groups. Attempts to isolate this species have not been successful so far, suggesting that $\mathrm{H}(\mathrm{D}) \mathrm{Cl}$ elimination and cyclometalation are thermodynamically favoured. It is worth noting that the rhodium analogue 9 is much less stable under acidic conditions and rapidly decomposes to the triazolium salt and an inorganic rhodium species.

Transmetalation of the silver triazolylidene with $N$-mesityl substituents derived from $\mathbf{5 c}\left(\mathbf{B F}_{4}\right)$ and $\mathbf{6 c}\left(\mathbf{B F}_{4}\right)$ with $\left[\mathrm{RhCp}^{*} \mathrm{Cl}_{2}\right]_{2}$ did not proceed. While the formation of a white precipitate and a color change from dark red to orange suggested transfer of the carbene to rhodium, ${ }^{1} \mathrm{H}$ NMR analysis of the crude product showed broad resonances which were not conclusive. Unambiguous identification of the species was not achieved due to rapid decomposition of the product, both in solution and in the solid state, yielding triazolium starting material. Presumably the mesityl group inhibits chelation of the ditriazolylidene ligand because of steric interactions with the $\mathrm{Cp}^{*}$ ligand. With $\mathrm{N}$-phenyl substituents, such instability issues are circumvented through $\mathrm{C}-\mathrm{H}$ bond activation and cyclometalation.

\section{Base-mediated metalation}

When ligand precursor $\mathbf{5 b}(\mathbf{I})$ was reacted directly with $\mathrm{MCl}_{3}$ $(\mathrm{M}=\mathrm{Rh}$ or Ir) in the presence of $\mathrm{KO} t \mathrm{Bu}$ as base to deprotonate the triazolium salt, the $\mathrm{Cp}^{*}$-free bis(homoleptic) complexes $\mathbf{1 3}$ and 14 were obtained (Scheme 3). Chelation of the triazolylidene was supported by the desymmetrization of the linker $\mathrm{CH}_{2}$ groups, which appeared as multiplets between 3.1 and $2.0 \mathrm{ppm}$ in the ${ }^{1} \mathrm{H}$ NMR spectrum. Similarly to complexes 8-10, two sets of signals for the phenyl groups indicated that one phenyl substituent is cyclometalated while the other is

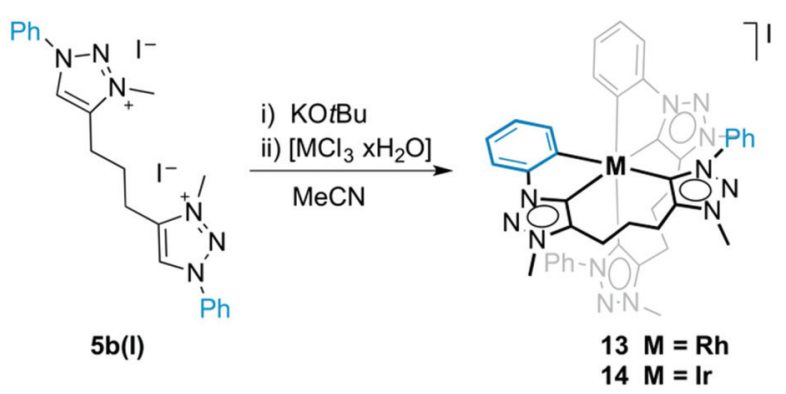

Scheme 3 Synthesis of complex 13 and 14 by base-mediated metalation. 
not. The ${ }^{13} \mathrm{C}\left\{{ }^{1} \mathrm{H}\right\}$ NMR spectrum of the rhodium complex 13 showed three doublet resonances in the low field region. Based on the larger coupling constant, the most deshielded signals at $\delta_{\mathrm{C}} 176.2$ and $171.3\left({ }^{1} J_{\mathrm{CRh}}=34.3\right.$ and $30.2 \mathrm{~Hz}$, respectively) were attributed to the triazolylidene carbon, while the resonance at $\delta_{\mathrm{C}} 164.9\left({ }^{1} J_{\mathrm{CRh}}=25.7 \mathrm{~Hz}\right)$ was assigned to the cyclometalated phenyl carbon. The Rh-C coupling constants for $\mathbf{1 3}$ are smaller than those of $\mathbf{8}$, which is probably a direct consequence of the stronger trans influence of the C,C,C-tridentate ligand in octahedral $\mathbf{1 3}$ as compared to $\mathrm{Cp}^{*}$ in complex 8. A meridional coordination mode of the ligand is tentatively surmised from the small chemical shift difference of the central methylene group in the linker (multiplet at $\delta_{\mathrm{H}}$ 2.08). When coordinating facially as in complex $\mathbf{8}$, these protons are magnetically more distinct and appear at 2.33 and $1.62 \mathrm{ppm}$. The ${ }^{1} \mathrm{H}$ NMR spectrum of $\mathbf{1 4}$ is very similar to that of 13 although the $\mathrm{H}_{\text {ortho }}$ and $\mathrm{H}_{\text {meta }}$ signals are broad for 14 . The metal-bound carbons are more shielded than those of $\mathbf{1 3}$ and resonate at $\delta_{\mathrm{C}} 158.9$ and $152.4\left(\mathrm{C}_{\text {trz }}\right)$ and at $\delta_{\mathrm{C}} 147.9$ $\left(\mathrm{C}_{\text {phenyl }}\right)$.

A single crystal structure determination of complex 13 confirmed the bis-homoleptic structure with a cyclometalated phenyl group for each ditriazolylidene ligand, thus producing a distorted octahedral geometry around the rhodium center (Fig. 5). In contrast to complexes 8-10 with a facially coordinating dicarbene ligand, the same ligand now adopts a meridional coordination mode in complex 13 with the two cyclometalated phenyl units in mutual cis position. The cyclometalated phenyl ring is coplanar with the adjacent triazolylidene heterocycle. The $\mathrm{C}_{\text {trz }}-\mathrm{Rh}$ bond trans to $\mathrm{C}_{\text {phenyl }}$ is $0.05 \AA$ longer than the $\mathrm{C}_{\mathrm{trz}}-\mathrm{Rh}$ bond trans to a carbene, which is presumably imposed by steric constraints imparted by the chelating bonding mode rather than distinct trans influences. One



Fig. 5 ORTEP representation of complex 13 (50\% probability ellipsoids, $\mathrm{I}^{-}$counterion, hydrogen atoms, and co-crystallized $\mathrm{CH}_{2} \mathrm{Cl}_{2}$ molecule omitted for clarity); selected bond lengths: Rh-C1 2.041(3) $\AA$, Rh-C4 2.071(3) Å, Rh-C14 2.098(3) Å; selected bond angles: C1-Rh-C4 80.22 $(13)^{\circ}, \mathrm{C} 1-\mathrm{Rh}-\mathrm{C} 1491.79(14)^{\circ}, \mathrm{C} 4-\mathrm{Rh}-\mathrm{C} 14171.87(13)^{\circ}, \mathrm{C} 1-\mathrm{Rh}-\mathrm{C}_{\text {trans }}$ $164.32(13)^{\circ}$.

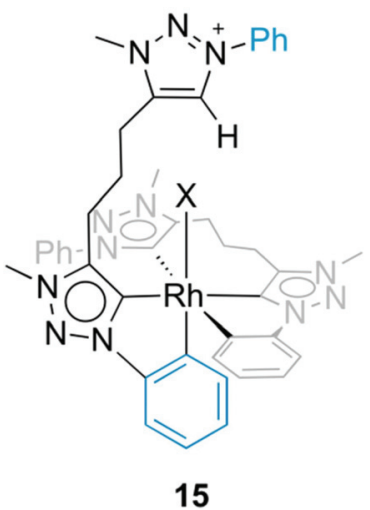

Fig. 6 Intermediate species 15 with a $\mathrm{C}_{\mathrm{trz}}, \mathrm{C}_{\mathrm{Ph}}$-bidentate coordinating ligand containing a pendant triazolium unit.

triazolylidene ring is substantially more constrained by the rigid five-membered metalacycle, while the other carbene is part of a more flexible eight-membered metalacyclic motif.

Formation of complex 13 was investigated in more detail by performing the synthesis at different temperatures. When the reaction was carried out at room temperature instead of MeCN reflux temperature, the triazolium salt $\mathbf{5 b}(\mathbf{I})$ was the only species observed by ${ }^{1} \mathrm{H}$ NMR spectroscopy after $18 \mathrm{~h}$. Upon heating to $60{ }^{\circ} \mathrm{C}$, complex 13 started to form, and in addition, an intermediate was detected by NMR spectroscopy that was identified as complex 15 (Fig. 6). The triazolium proton of $\mathbf{1 5}$ appeared in the ${ }^{1} \mathrm{H}$ NMR spectrum at $\delta_{\mathrm{H}} 8.79$ while the phenyl proton signals showed the diagnostic signature of both a pending phenyl group and an ortho-metalated phenylene unit, which were in equal intensity yet at distinct chemical shift from the $\mathrm{C}_{\text {phenyl }}$ resonances of the tridentate ligand. Moreover, mass spectrometry showed a signal at 409 amu, which corroborates the calculated mass for the dicationic fragment of $[\mathbf{1 5}-\mathrm{X}]^{2+}$ $\left(m / z=409.4\right.$ calculated for $\left.\left[\mathrm{C}_{42} \mathrm{H}_{43} \mathrm{RhN}_{12}\right]^{2+}\right) .{ }^{32}$ Upon further heating, this intermediate $\mathbf{1 5}$ evolved to the bis(homoleptic) complex 13 exclusively. Complex 15 is related to intermediate 12 detected en route to the tridentate coordinating dicarbene iridium complex 10 ( $c f$. Fig. 4). The formation of a $\mathrm{C}_{\text {trz }}, \mathrm{C}_{\text {phenyl}}{ }^{-}$ bidentate coordinated complex with a pendant triazolium species supports our previous observation that cyclometalation and $\mathrm{C}_{\text {phenyl }}-\mathrm{H}$ bond activation take place prior to coordination of the second triazolylidene ligand. Cyclometalation may be a key driver in the formation of complex 13, since the basemediated metalation reaction did not proceed with the $N$-ethyl or $N$-mesityl analogues $\mathbf{5 a ( I )}$ and $\mathbf{5 c}(\mathbf{I})$, respectively under otherwise identical conditions. Instead, only triazolium starting materials were observed by NMR spectroscopy.

\section{Conclusions}

A series of ditriazolylidene rhodium and iridium complexes containing alkyl- or ether-linkers between the triazolylidene bonding sites were derived from commercially available 
diynes. Ligand parameters and specifically the $\mathrm{N}$-substituents on the triazole heterocycle critically dictate the bonding mode of the dicarbene ligand. In particular, $N$-phenyl substituted triazolylidenes lead in all cases to ortho-metalation of one of the phenyl rings and to a $\mathrm{C}_{\mathrm{trz}}, \mathrm{C}_{\mathrm{trz}}, \mathrm{C}_{\mathrm{Ph}}$-tridentate ligand coordination mode. The $\mathrm{C}_{\mathrm{Ph}}-\mathrm{H}$ bond activation process is spontaneous and the isolation of a $\mathrm{C}_{\mathrm{trz}}, \mathrm{C}_{\mathrm{Ph}}$-bidentated intermediate suggests that this bond activation occurs prior to chelation of the second carbene. Stability studies under acidic conditions involving the $\mathrm{C}_{\mathrm{trz}}, \mathrm{C}_{\mathrm{trz}}, \mathrm{C}_{\mathrm{Ph}}$-tridentate coordinated iridium complex indicate that the $\mathrm{Ir}-\mathrm{C}_{\mathrm{trz}}$ bonds are robust while the Ir$\mathrm{C}_{\mathrm{Ph}}$ bond is kinetically labile and formed reversibly. Moreover, depending on the applied metalation procedure, the ligand coordinates either meridionally or facially. This coordinative flexibility paired with the hemilability of the $\mathrm{C}_{\mathrm{Ph}}$-Ir bond are attractive features for catalysis. The potential of these complexes as catalysts in, for example, hydrogen transfer reactions is currently under investigation.

\section{Experimental section}

\section{General comments}

All reagents were used as received from commercial suppliers. Unless specified, NMR spectra were recorded at $25{ }^{\circ} \mathrm{C}$ on Varian spectrometers operating at 300,400 or $500 \mathrm{MHz}\left({ }^{1} \mathrm{H}\right.$ NMR) and 75, 100 or $125 \mathrm{MHz}\left({ }^{13} \mathrm{C}\left\{{ }^{1} \mathrm{H}\right\}\right.$ NMR) respectively. Chemical shifts ( $\delta$ in ppm, coupling constants $J$ in $\mathrm{Hz}$ ) were referenced to external $\mathrm{SiMe}_{4}\left({ }^{1} \mathrm{H},{ }^{13} \mathrm{C}\left\{{ }^{1} \mathrm{H}\right\}\right)$. Assignments are based on homo- and hetero-nuclear shift correlation spectroscopy. High-resolution mass spectrometry was carried out with a Micromass/Waters Corp. USA liquid chromatography with an electrospray source. Elemental analyses were performed at UCD Microanalytic Laboratory using an Exeter Analytical CE-440 elemental analyser. Residual solvents were identified by NMR spectroscopy.

\section{General procedure for the synthesis of ditriazoles 3 and 4}

Method A: A mixture of the corresponding diyne (1 mol equiv.), azide (2.2 mol equiv.), $\mathrm{CuSO}_{4}(2 \mathrm{~mol} \%)$ and sodium ascorbate (20 $\mathrm{mol} \%$ ) in a $1: 1$ mixture of THF : $\mathrm{H}_{2} \mathrm{O}$ was irradiated in a microwave reactor at $100{ }^{\circ} \mathrm{C}$ for $2 \mathrm{~h}$ using high absorption. The THF was removed under reduced pressure and the organics were extracted with $\mathrm{CH}_{2} \mathrm{Cl}_{2}(2 \times 50 \mathrm{~mL})$. The combined organics were washed with dilute $\left(\mathrm{NH}_{4}\right)(\mathrm{OH})$ (aq., $\left.50 \mathrm{~mL}\right)$, water $(2 \times$ $50 \mathrm{~mL}$ ) and saturated $\mathrm{NaCl}$ solution (aq. $1 \times 40 \mathrm{~mL}$ ), dried over anhydrous $\mathrm{Na}_{2} \mathrm{SO}_{4}$, filtered and all volatiles removed under reduced pressure yielding the ditriazole product.

Method B: EtI ( 1 mol equiv.) and $\mathrm{NaN}_{3}$ ( 4 mol equiv.) were added to a microwave vessel with $1: 1$ of $\mathrm{THF}: \mathrm{H}_{2} \mathrm{O}(20 \mathrm{~mL})$ and stirred at room temperature for $48 \mathrm{~h}$. To this mixture the corresponding diyne ( $0.33 \mathrm{~mol}$ equiv.), $\mathrm{CuSO}_{4}(14 \mathrm{~mol} \%)$ and copper powder ( $5 \mathrm{~mol} \%$ ) were added and the mixture was irradiated in a microwave reactor at $100{ }^{\circ} \mathrm{C}$ for $2 \mathrm{~h}$ using high absorption. The THF was removed under reduced pressure and the organic residue was extracted with $\mathrm{CH}_{2} \mathrm{Cl}_{2}(2 \times 50 \mathrm{~mL})$.
The crude reaction mixture was filtered through a short column of silica with a $\mathrm{CH}_{2} \mathrm{Cl}_{2}$ /acetone solution $(1: 1,300 \mathrm{~mL})$ until all product was collected as indicated by TLC. The solvent was removed under reduced pressure giving the ditriazole product as an oil.

Synthesis of 3a. According to method B, EtI $(2.8 \mathrm{~g}$, $18 \mathrm{mmol}), \mathrm{NaN}_{3}(4.8 \mathrm{~g}, 74 \mathrm{mmol})$, THF $(5 \mathrm{~mL}), \mathrm{H}_{2} \mathrm{O}(5 \mathrm{~mL})$, 1,6-heptadiyne $(0.62 \mathrm{~mL}, 5.4 \mathrm{mmol}), \mathrm{CuSO}_{4}(0.189 \mathrm{~g}$, $0.756 \mathrm{mmol})$ and copper powder $(0.017 \mathrm{~g}, 0.270 \mathrm{mmol})$ were reacted in a microwave reactor for $2 \mathrm{~h}$. After purification, the product was obtained as a yellow oil (0.92 g, 72\%). ${ }^{1} \mathrm{H}$ NMR $\left(\mathrm{CD}_{3} \mathrm{CN}, 400 \mathrm{MHz}\right): \delta 7.54\left(\mathrm{~s}, 2 \mathrm{H}, \mathrm{H}_{\mathrm{trz}}\right), 4.30\left(\mathrm{q}, 4 \mathrm{H},{ }^{3} J_{\mathrm{HH}}=7.3\right.$ $\mathrm{Hz}, \mathrm{NCH}_{2}$ ), $2.67\left(\mathrm{t}, 4 \mathrm{H},{ }^{3} \mathrm{~J}_{\mathrm{HH}}=7.5 \mathrm{~Hz}, \mathrm{C}_{\mathrm{trz}} \mathrm{CH}_{2}\right.$ ), 1.94 (quintet, $\left.2 \mathrm{H},{ }^{3} J_{\mathrm{HH}}=7.5 \mathrm{~Hz}, \mathrm{C}_{\mathrm{trz}} \mathrm{CH}_{2} \mathrm{CH}_{2}\right), 1.41\left(\mathrm{t}, 6 \mathrm{H},{ }^{3} J_{\mathrm{HH}}=7.3 \mathrm{~Hz}\right.$, $\left.\mathrm{NCH}_{2} \mathrm{CH}_{3}\right) \cdot{ }^{13} \mathrm{C}\left\{{ }^{1} \mathrm{H}\right\}$ NMR $\left(\mathrm{CD}_{3} \mathrm{CN}, 100 \mathrm{MHz}\right): \delta 148.1\left(\mathrm{C}_{\text {trz }}\right)$, $121.8\left(\mathrm{C}_{\mathrm{trz}}-\mathrm{H}\right), 45.7\left(\mathrm{NCH}_{2}\right), 30.0\left(\mathrm{CCH}_{2} \mathrm{CH}_{2}\right), 25.6\left(\mathrm{CCH}_{2} \mathrm{CH}_{2}\right)$, $15.8\left(\mathrm{NCH}_{2} \mathrm{CH}_{2}\right)$. ESI-MS $(\mathrm{m} / \mathrm{z}): 235.1676$, calcd for $\left[\mathrm{C}_{11} \mathrm{H}_{19} \mathrm{~N}_{6}\right]^{+}$ 235.1671 .

Synthesis of $\mathbf{3 b}$. According to method A, 1,6-heptadiyne (0.53 mL, $4.62 \mathrm{mmol}$ ), phenyl azide (1.38 g, $11.56 \mathrm{mmol})$, $\mathrm{CuSO}_{4}(0.015 \mathrm{~g}, 94 \mu \mathrm{mol})$, sodium ascorbate $(0.183 \mathrm{~g}$, $0.924 \mathrm{mmol})$, THF $(8 \mathrm{~mL})$ and $\mathrm{H}_{2} \mathrm{O}(8 \mathrm{~mL})$ were reacted in a microwave reactor for $2 \mathrm{~h}$. After purification, the product was obtained as an off-white solid $(1.83 \mathrm{~g}, 95 \%)$. Analytically pure product was obtained by recrystallization from minimal amounts of THF/cyclohexane $(1: 1) .{ }^{1} \mathrm{H}$ NMR $\left(\mathrm{CDCl}_{3}\right.$, $400 \mathrm{MHz}): \delta 7.80\left(\mathrm{~s}, 2 \mathrm{H}, \mathrm{H}_{\mathrm{trz}}\right), 7.70-7.66\left(\mathrm{~m}, 4 \mathrm{H}, \mathrm{H}_{\text {ortho }}\right)$, $7.49-7.43\left(\mathrm{~m}, 4 \mathrm{H}, \mathrm{H}_{\text {meta }}\right), 7.37\left(\mathrm{tt}, 2 \mathrm{H},{ }^{3} J_{\mathrm{HH}}=7.4 \mathrm{~Hz},{ }^{4} J_{\mathrm{HH}}=1.2\right.$ $\mathrm{Hz}, \mathrm{H}_{\text {para }}$ ), 2.89 (t, $4 \mathrm{H},{ }^{3} J_{\mathrm{HH}}=7.4 \mathrm{~Hz}, \mathrm{C}_{\mathrm{trz}} \mathrm{CH}_{2}$ ), 2.18 (quintet, $\left.2 \mathrm{H},{ }^{3} \mathrm{~J}_{\mathrm{HH}}=7.4 \mathrm{~Hz}, \mathrm{CCH}_{2} \mathrm{CH}_{2}\right) \cdot{ }^{13} \mathrm{C}\left\{{ }^{1} \mathrm{H}\right\} \mathrm{NMR}\left(\mathrm{CDCl}_{3}, 100 \mathrm{MHz}\right)$ : $\delta 148.3\left(\mathrm{C}_{\text {trz }}\right), 137.2\left(\mathrm{C}_{\text {ipso }}\right) 129.7\left(\mathrm{C}_{\text {meta }}\right), 128.5$ ( $\left.\mathrm{C}_{\text {para }}\right), 120.4$ $\left(\mathrm{C}_{\text {ortho }}\right), 119.4\left(\mathrm{C}_{\mathrm{trz}}-\mathrm{H}\right), 29.0\left(\mathrm{C}_{\mathrm{trz}} \mathrm{CH}_{2} \mathrm{CH}_{2}\right), 24.9\left(\mathrm{C}_{\mathrm{trz}} \mathrm{CH}_{2}\right)$. ESI-MS $(\mathrm{m} / \mathrm{z}): 331.1677$, calcd for $\left[\mathrm{C}_{19} \mathrm{H}_{19} \mathrm{~N}_{6}\right]^{+} 331.1671$. Anal calcd for $\mathrm{C}_{19} \mathrm{H}_{18} \mathrm{~N}_{6}$ (330.39): C, 69.07; H, 5.49; N, 25.44\%. Found: C, 68.58; H, 5.49; N, 25.19\%.

Synthesis of 3c. According to method A, 1,6-heptadiyne (0.13 $\mathrm{mL}, 1.13 \mathrm{mmol})$, mesityl azide (0.40 g, $2.48 \mathrm{mmol})$, $\mathrm{CuSO}_{4}(0.004 \mathrm{~g}, 23 \mu \mathrm{mol})$, sodium ascorbate $(0.045 \mathrm{~g}$, $0.23 \mathrm{mmol})$, THF $(9 \mathrm{~mL})$ and $\mathrm{H}_{2} \mathrm{O}(9 \mathrm{~mL})$ were reacted in a microwave reactor for $2 \mathrm{~h}$. After purification, the product was obtained as an off-white solid (0.37 g, 80\%). Analytically pure material was obtained by recrystallization from hot cyclohexane $(30 \mathrm{~mL})$ with a minimum amount of THF.

${ }^{1} \mathrm{H}$ NMR ( $\left.\mathrm{CDCl}_{3}, 400 \mathrm{MHz}\right): \delta 7.41\left(\mathrm{~s}, 2 \mathrm{H}, \mathrm{H}_{\text {trz }}\right), 6.96(\mathrm{~s}, 4 \mathrm{H}$, $\left.\mathrm{H}_{\mathrm{Mes}}\right), 2.92\left(\mathrm{t}, 4 \mathrm{H},{ }^{3} J_{\mathrm{HH}}=7.6 \mathrm{~Hz}, \mathrm{C}_{\text {trz }} \mathrm{CH}_{2}\right), 2.33(\mathrm{~s}, 6 \mathrm{H}$, $\mathrm{CH}_{3-\text { para }}$ ), 2.23 (quintet, $2 \mathrm{H},{ }^{3} J_{\mathrm{HH}}=7.6 \mathrm{~Hz}, \mathrm{CCH}_{2} \mathrm{CH}_{2}$ ), 1.95 (s, $\left.12 \mathrm{H}, \mathrm{CH}_{3 \text {-ortho }}\right) \cdot{ }^{13} \mathrm{C}\left\{{ }^{1} \mathrm{H}\right\} \mathrm{NMR}\left(\mathrm{CDCl}_{3}, 100 \mathrm{MHz}\right): \delta 147.3\left(\mathrm{C}_{\text {trz }}\right)$, 139.9 ( $\left.\mathrm{C}_{\text {para }}\right), 135.2\left(\mathrm{C}_{\text {ortho }}\right), 133.8\left(\mathrm{C}_{\text {ipso }}\right), 129.1\left(\mathrm{C}_{\text {meta }}\right), 123.0$ $\left(\mathrm{C}_{\mathrm{trz}}-\mathrm{H}\right), 29.3\left(\mathrm{CCH}_{2} \mathrm{CH}_{2}\right), 25.1\left(\mathrm{C}_{\mathrm{trz}} \mathrm{CH}_{2}\right), 21.2\left(\mathrm{CH}_{3-\text { para }}\right), 17.4$ $\left(\mathrm{CH}_{3 \text {-ortho }}\right)$. ESI-MS (m/z): 415.2600, calcd for $\left[\mathrm{C}_{25} \mathrm{H}_{31} \mathrm{~N}_{6}\right]^{+}$ 415.2610. Anal calcd for $\mathrm{C}_{25} \mathrm{H}_{30} \mathrm{~N}_{6}$ (414.55): C, 72.43; H, 7.29; N, 20.27\%. Found: C, 72.12; H, 7.38; N, 19.99\%.

Synthesis of 4a. According to method B, EtI (624 mg, $4 \mathrm{mmol}), \mathrm{NaN}_{3}(1 \mathrm{~g}, 16 \mathrm{mmol})$, THF ( $\left.9 \mathrm{~mL}\right), \mathrm{H}_{2} \mathrm{O}(9 \mathrm{~mL})$, propargyl ether $(0.21 \mathrm{~mL}, 2 \mathrm{mmol}), \mathrm{CuSO}_{4}(100 \mathrm{mg}, 0.4 \mathrm{mmol})$ and copper powder $(70 \mathrm{mg}, 0.1 \mathrm{mmol}$ ) were reacted in a micro- 
wave reactor for $2 \mathrm{~h}$. Purification was carried out as per method A giving the product as a red oil $(0.34 \mathrm{~g}, 71 \%) .{ }^{1} \mathrm{H}$ NMR $\left(\mathrm{CDCl}_{3}, 400 \mathrm{MHz}\right): \delta 7.59\left(\mathrm{~s}, 2 \mathrm{H}, \mathrm{H}_{\text {trz }}\right), 4.71(\mathrm{~s}, 4 \mathrm{H}$, $\left.\mathrm{OCH}_{2}\right), 4.40\left(\mathrm{q}, 4 \mathrm{H},{ }^{3} J_{\mathrm{HH}}=7.4 \mathrm{~Hz}, \mathrm{NCH}_{3}\right), 1.55\left(\mathrm{t}, 4 \mathrm{H},{ }^{3} J_{\mathrm{HH}}=\right.$ $\left.7.4 \mathrm{~Hz}, \mathrm{NCH}_{2} \mathrm{CH}_{3}\right) .{ }^{13} \mathrm{C}\left\{{ }^{1} \mathrm{H}\right\} \mathrm{NMR}\left(\mathrm{CDCl}_{3}, 100 \mathrm{MHz}\right): \delta 144.8$ $\left(\mathrm{C}_{\text {trz }}\right), \quad 122.2 \quad\left(\mathrm{C}_{\text {trz }}-\mathrm{H}\right), \quad 63.8 \quad\left(\mathrm{OCH}_{2}\right), \quad 45.4 \quad\left(\mathrm{NCH}_{3}\right), \quad 15.6$ $\left(\mathrm{NCH}_{2} \mathrm{CH}_{3}\right)$. ESI-MS $(\mathrm{m} / \mathrm{z}): 237.1473$, calcd for $\left[\mathrm{C}_{10} \mathrm{H}_{17} \mathrm{~N}_{6} \mathrm{O}\right]^{+}$ 237.1464. The oily nature prevented full purification to microanalytical standards.

Synthesis of $4 \mathbf{b}$. According to method A, propargyl ether (0.6 mL, $5.82 \mathrm{mmol}$ ), phenyl azide (1.73 g, $14.5 \mathrm{mmol}$ ), $\mathrm{CuSO}_{4}$ (0.019 g, $0.12 \mathrm{mmol})$, sodium ascorbate $(0.230 \mathrm{~g}, 1.16 \mathrm{mmol})$, THF $(8 \mathrm{~mL})$ and $\mathrm{H}_{2} \mathrm{O}(8 \mathrm{~mL})$ were reacted in a microwave reactor for $2 \mathrm{~h}$. After purification, the product was obtained as an off-white solid (1.45 g, 95\%). Analytically pure product was obtained by recrystallization from minimum amounts of $\mathrm{THF} /$ cyclohexane (1:1). ${ }^{1} \mathrm{H}$ NMR $\left(\mathrm{CDCl}_{3}, 400 \mathrm{MHz}\right): \delta 8.05(\mathrm{~s}, 2 \mathrm{H}$, $\left.\mathrm{H}_{\text {trz }}\right)$, 7.73-7.69 (m, 4H, $\left.\mathrm{H}_{\text {ortho }}\right), 7.52-7.47\left(\mathrm{~m}, 4 \mathrm{H}, \mathrm{H}_{\text {meta }}\right)$, $7.44-7.39\left(\mathrm{~m}, 2 \mathrm{H},{ }^{3} J_{\mathrm{HH}}=7.4 \mathrm{~Hz},{ }^{4} J_{\mathrm{HH}}=1.2 \mathrm{~Hz}, \mathrm{H}_{\text {para }}\right), 4.84(\mathrm{~s}$, $\left.4 \mathrm{H}, \mathrm{OCH}_{2}\right) .{ }^{13} \mathrm{C}\left\{{ }^{1} \mathrm{H}\right\} \mathrm{NMR}\left(\mathrm{CDCl}_{3}, 100 \mathrm{MHz}\right): \delta 145.4\left(\mathrm{C}_{\text {trz }}\right)$, $137.0\left(\mathrm{C}_{\text {ipso }}\right) 129.8\left(\mathrm{C}_{\text {meta }}\right), 128.9\left(\mathrm{C}_{\text {para }}\right), 121.3\left(\mathrm{C}_{\mathrm{trz}}-\mathrm{H}\right), 120.6$ $\left(\mathrm{C}_{\text {ortho }}\right), 63.7\left(\mathrm{OCH}_{2}\right)$. ESI-MS $(\mathrm{m} / \mathrm{z}): 333.1473$, calcd for $\left[\mathrm{C}_{18} \mathrm{H}_{17} \mathrm{~N}_{6} \mathrm{O}\right]^{+}$333.1464. Anal calcd for $\mathrm{C}_{18} \mathrm{H}_{16} \mathrm{~N}_{6} \mathrm{O}$ (332.36): $\mathrm{C}$, 65.05; H, 4.85; N, 25.29\%. Found: C, 64.64; H, 4.58; N, 24.97\%.

Synthesis of 4c. According to method A, propargyl ether (0.12 mL, $1.13 \mathrm{mmol})$, mesityl azide (0.4 g, $2.48 \mathrm{mmol}), \mathrm{CuSO}_{4}$ (4 mg, $0.023 \mathrm{mmol}$ ), sodium ascorbate (45 $\mathrm{mg}, 0.23 \mathrm{mmol}$ ), THF $(8 \mathrm{~mL})$ and $\mathrm{H}_{2} \mathrm{O}(8 \mathrm{~mL})$ were reacted in a microwave reactor for $2 \mathrm{~h}$. After solvent evaporation, the crude product was obtained as an amber oil (0.4 g, 85\%). It was purified by column chromatography $\left(\mathrm{SiO}_{2} ; \mathrm{Et}_{2} \mathrm{O}\right.$, then $\left.\mathrm{CH}_{2} \mathrm{Cl}_{2}\right)$. An analytically pure sample was obtained by recrystallization from minimum quantities of $\mathrm{THF} /$ cyclohexane $(1: 1) .{ }^{1} \mathrm{H}$ NMR $\left(\mathrm{CDCl}_{3}, 400 \mathrm{MHz}\right): \delta 7.67\left(\mathrm{~s}, 2 \mathrm{H}, \mathrm{H}_{\text {trz }}\right), 6.98$ (s, $\left.4 \mathrm{H}, \mathrm{H}_{\mathrm{Mes}}\right), 4.87$ (s, 4H, $\left.\mathrm{OCH}_{2}\right), 2.34\left(\mathrm{~s}, 6 \mathrm{H}, \mathrm{CH}_{3 \text {-para }}\right), 1.96$ (s, 12H, $\mathrm{CH}_{3 \text {-ortho }}$ ). ${ }^{13} \mathrm{C}\left\{{ }^{1} \mathrm{H}\right\}$ NMR $\left(\mathrm{CDCl}_{3}, 100 \mathrm{MHz}\right): \delta 144.6\left(\mathrm{C}_{\text {trz }}\right), 140.1\left(\mathrm{C}_{\text {para }}\right)$ 135.2 ( $\left.\mathrm{C}_{\text {ortho }}\right), 133.5$ ( $\left.\mathrm{C}_{\text {ipso }}\right), 129.2\left(\mathrm{C}_{\text {meta }}\right), 124.9\left(\mathrm{C}_{\text {trz }}-\mathrm{H}\right), 63.8$ $\left(\mathrm{OCH}_{2}\right), 21.2\left(\mathrm{CH}_{3 \text {-para }}\right), 17.4\left(\mathrm{CH}_{3 \text {-ortho }}\right)$. ESI-MS $(\mathrm{m} / \mathrm{z})$ : 417.2398, calcd for $\left[\mathrm{C}_{24} \mathrm{H}_{29} \mathrm{~N}_{6} \mathrm{O}\right]^{+}$417.2403. Anal calcd for $\mathrm{C}_{24} \mathrm{H}_{28} \mathrm{~N}_{6} \mathrm{O}$ (416.52): C, 69.21; H, 6.78; N, 20.18\%. Found: C, 69.44; H, $6.90 ; \mathrm{N}, 19.93 \%$.

\section{General procedure for alkylation of ditriazoles (5a-c(I), $6 \mathrm{a}-\mathrm{c}(\mathrm{I}))$}

A mixture of ditriazole ( 1 mol equiv.) and MeI (excess) were added to a pressure tube with $\mathrm{MeCN}(10 \mathrm{~mL})$. The mixture was heated for a set time at reflux. After cooling to room temperature the product was precipitated by addition of $\mathrm{Et}_{2} \mathrm{O}(80 \mathrm{ml})$ and the ditriazolium salt was isolated by centrifugation. The crude product was suspended in $\mathrm{MeCN}(10 \mathrm{~mL})$ and precipitated again with $\mathrm{Et}_{2} \mathrm{O}(80 \mathrm{~mL})$ and isolated by centrifugation. This purification procedure was repeated once more.

Synthesis of $5 \mathbf{a}(\mathbf{I})$. According to the general procedure, 3a (0.55 g, $2.35 \mathrm{mmol})$ and MeI (3.33 g, $23.5 \mathrm{mmol})$ and after $21 \mathrm{~h}$ of reflux, the product was obtained as a dark red waxy solid (1.08 g, 89\%). ${ }^{1} \mathrm{H}$ NMR ( $\left.\mathrm{CD}_{3} \mathrm{CN}, 400 \mathrm{MHz}\right): \delta 8.87$ (s, 2H, $\mathrm{H}_{\text {trz }}$ ), 4.59 (q, $\left.4 \mathrm{H},{ }^{3} J_{\mathrm{HH}}=7.3 \mathrm{~Hz}, \mathrm{NCH}_{2}\right), 4.20\left(\mathrm{~s}, 6 \mathrm{H}, \mathrm{NCH}_{3}\right)$, $3.06\left(\mathrm{t}, 4 \mathrm{H},{ }^{3} J_{\mathrm{HH}}=7.7 \mathrm{~Hz}, \mathrm{C}_{\mathrm{trz}} \mathrm{CH}_{2}\right.$ ), 2.22 (quintet, $2 \mathrm{H},{ }^{3} J_{\mathrm{HH}}=$ $\left.7.7 \mathrm{~Hz}, \mathrm{C}_{\mathrm{trz}} \mathrm{CH}_{2} \mathrm{CH}_{2}\right), 1.59\left(\mathrm{t}, 6 \mathrm{H},{ }^{3} J_{\mathrm{HH}}=7.3 \mathrm{~Hz}, \mathrm{NCH}_{2} \mathrm{CH}_{3}\right) .{ }^{13} \mathrm{C}$ $\left\{{ }^{1} \mathrm{H}\right\}$ NMR $\left(\mathrm{CD}_{3} \mathrm{CN}, 100 \mathrm{MHz}\right): \delta 143.4\left(\mathrm{C}_{\mathrm{trz}}\right), 128.6\left(\mathrm{C}_{\mathrm{trz}}-\mathrm{H}\right)$, $49.3 \quad\left(\mathrm{NCH}_{2}\right), \quad 38.2 \quad\left(\mathrm{NCH}_{3}\right), \quad 24.3 \quad\left(\mathrm{C}_{\mathrm{trz}} \mathrm{CH}_{2} \mathrm{CH}_{2}\right), \quad 22.4$ $\left(\mathrm{C}_{\text {trz }} \mathrm{CH}_{2} \mathrm{CH}_{2}\right), 13.9\left(\mathrm{NCH}_{2} \mathrm{CH}_{3}\right)$. ESI-MS (m/z): 132.0580, calcd for $\left[\mathrm{C}_{13} \mathrm{H}_{24} \mathrm{~N}_{6}\right]^{2+}$ 132.1031. Because of the oily consistency of the product, we were unable to obtain satisfactory microanalysis even after repeated precipitations (see also ESI $\dagger$ ).

Synthesis of $5 \mathbf{b}(\mathrm{I})$. Compound $3 \mathrm{~b}(0.50 \mathrm{~g}, 1.51 \mathrm{mmol})$ and MeI (0.94 mL, $15.1 \mathrm{mmol})$ were refluxed in MeCN for $20 \mathrm{~h}$ according to the general procedure. The formed precipitate was collected on a sintered funnel and washed twice with $\mathrm{Et}_{2} \mathrm{O}$ $(3 \times 40 \mathrm{~mL})$. After solvent evaporation, the product was obtained as a white solid $(0.663 \mathrm{~g}, 71 \%)$. A microanalytically pure sample was obtained by slow diffusion of $\mathrm{Et}_{2} \mathrm{O}$ into a MeCN solution containing the ditriazolium salt. ${ }^{1} \mathrm{H}$ NMR $\left(\left(\mathrm{CD}_{3}\right)_{2} \mathrm{SO}, 400 \mathrm{MHz}\right): \delta 9.56\left(\mathrm{~s}, 2 \mathrm{H}, \mathrm{H}_{\mathrm{trz}}\right), 8.05-8.02(\mathrm{~m}, 4 \mathrm{H}$, $\left.\mathrm{H}_{\text {ortho }}\right), 7.80-7.73\left(\mathrm{~m}, 6 \mathrm{H}, \mathrm{H}_{\mathrm{Ph}}\right), 4.39\left(\mathrm{~s}, 6 \mathrm{H}, \mathrm{NCH}_{3}\right), 3.15(\mathrm{t}, 4 \mathrm{H}$, ${ }^{3} J_{\mathrm{HH}}=7.5 \mathrm{~Hz}, \mathrm{C}_{\mathrm{trz}} \mathrm{CH}_{2}$ ), 2.32 (quintet, $2 \mathrm{H},{ }^{3} \mathrm{~J}_{\mathrm{HH}}=7.5 \mathrm{~Hz}$, $\left.\mathrm{CCH}_{2} \mathrm{CH}_{2}\right) .{ }^{13} \mathrm{C}\left\{{ }^{1} \mathrm{H}\right\} \mathrm{NMR}\left(\left(\mathrm{CD}_{3}\right)_{2} \mathrm{SO}, 100 \mathrm{MHz}\right): \delta 144.1\left(\mathrm{C}_{\mathrm{trz}}\right)$, $134.8\left(\mathrm{C}_{\text {ipso }}\right) 131.7\left(\mathrm{C}_{\text {para }}\right), 130.5\left(\mathrm{C}_{\text {meta }}\right), 127.0\left(\mathrm{C}_{\text {trz }}-\mathrm{H}\right), 121.3$ $\left(\mathrm{C}_{\text {ortho }}\right), 38.2\left(\mathrm{NCH}_{3}\right), 23.1\left(\mathrm{CCH}_{2} \mathrm{CH}_{2}\right), 21.8\left(\mathrm{C}_{\mathrm{trz}} \mathrm{CH}_{2}\right)$. ESI-MS $(m / z): 180.0987$, calcd for $\left[\mathrm{C}_{21} \mathrm{H}_{24} \mathrm{~N}_{6}\right]^{2+}$ 180.1031. Anal calcd for $\mathrm{C}_{21} \mathrm{H}_{24} \mathrm{~N}_{6} \mathrm{I}_{2}$ (614.26): C, 41.06; H, 3.94; N, 13.68\%. Found: C, $41.05 ; \mathrm{H}, 3.88$; N, 13.64\%.

Synthesis of $5 \mathbf{c}(\mathrm{I})$. Compound $3 \mathrm{c}(0.34 \mathrm{~g}, 0.82 \mathrm{mmol})$ and MeI $(0.51 \mathrm{~mL}, 8.13 \mathrm{mmol})$ were refluxed in MeCN for $48 \mathrm{~h}$ and purified according to the general procedure, yielding $\mathbf{5 c}(\mathbf{I})$ as a yellow solid $(0.45 \mathrm{~g}, 79 \%)$. The product was recrystallized by slow diffusion of $\mathrm{Et}_{2} \mathrm{O}$ into an $\mathrm{MeCN}$ solution of the compound. ${ }^{1} \mathrm{H}$ NMR ( $\left.\mathrm{CD}_{3} \mathrm{CN}, 400 \mathrm{MHz}\right): \delta 9.04\left(\mathrm{~s}, 2 \mathrm{H}, \mathrm{H}_{\mathrm{trz}}\right), 7.15$ (s, $\left.4 \mathrm{H}, \mathrm{H}_{\mathrm{Mes}}\right), 4.32\left(\mathrm{~s}, 6 \mathrm{H}, \mathrm{NCH}_{3}\right), 3.17\left(\mathrm{t}, 4 \mathrm{H},{ }^{3} \mathrm{~J}_{\mathrm{HH}}=7.8 \mathrm{~Hz}\right.$, $\mathrm{C}_{\text {trz }} \mathrm{CH}_{2}$ ), 2.48 (quintet, $2 \mathrm{H},{ }^{3} J_{\mathrm{HH}}=7.8 \mathrm{~Hz}, \mathrm{CCH}_{2} \mathrm{CH}_{2}$ ), 2.37 (s, $\left.6 \mathrm{H}, \mathrm{CH}_{3 \text {-para }}\right), 2.10\left(\mathrm{~s}, 12 \mathrm{H}, \mathrm{CH}_{3 \text {-ortho }}\right) .{ }^{13} \mathrm{C}\left\{{ }^{1} \mathrm{H}\right\} \mathrm{NMR}\left(\mathrm{CD}_{3} \mathrm{CN}\right.$, $100 \mathrm{MHz}): \delta 145.4\left(\mathrm{C}_{\text {trz }}\right), 143.5$ ( $\left.\mathrm{C}_{\text {para }}\right), 135.7$ ( $\left.\mathrm{C}_{\text {ortho }}\right), 132.4$ $\left(\mathrm{C}_{\text {ipso }}\right), \quad 132.1 \quad\left(\mathrm{C}_{\mathrm{trz}}-\mathrm{H}\right), \quad 130.6 \quad\left(\mathrm{C}_{\text {meta }}\right), \quad 39.7 \quad\left(\mathrm{NCH}_{3}\right), \quad 24.6$ $\left(\mathrm{CCH}_{2} \mathrm{CH}_{2}\right), 23.9\left(\mathrm{C}_{\mathrm{trz}} \mathrm{CH}_{2}\right), 21.2\left(\mathrm{CH}_{3-\text { para }}\right), 17.8\left(\mathrm{CH}_{3 \text {-ortho }}\right)$. ESI-MS $(\mathrm{m} / \mathrm{z}): 222.1477$, calcd for $\left[\mathrm{C}_{27} \mathrm{H}_{36} \mathrm{~N}_{6}\right]^{+} 222.1500$. Anal calcd for $\mathrm{C}_{27} \mathrm{H}_{36} \mathrm{I}_{2} \mathrm{~N}_{6}$ (698.42): C, 46.43; H, 5.20; N, $12.03 \%$. Found: C, 46.11; H, 5.06; N, 11.94\%.

Synthesis of $6 \mathbf{a}(\mathrm{I})$. Compound $4 \mathbf{a}(0.85 \mathrm{~g}, 3.6 \mathrm{mmol})$ and $\mathrm{MeI}$ (0.9 mL, $14.4 \mathrm{mmol}$ ) were refluxed for 3 days in MeCN. After purification as described in the general procedure, the product was obtained as an off-white solid (1.44 g, 77\%), and further purified by recrystallization from $\mathrm{MeCN} / \mathrm{Et}_{2} \mathrm{O} .{ }^{1} \mathrm{H} \mathrm{NMR}$ $\left(\mathrm{CD}_{3} \mathrm{CN}, 400 \mathrm{MHz}\right): \delta 8.92\left(\mathrm{~s}, 2 \mathrm{H}, \mathrm{H}_{\mathrm{trz}}\right), 5.05\left(\mathrm{~s}, 4 \mathrm{H}, \mathrm{OCH}_{2}\right)$, $4.64\left(\mathrm{q}, 4 \mathrm{H}, J_{\mathrm{HH}}=7.3 \mathrm{~Hz}, \mathrm{NCH}_{2}\right), 4.26\left(\mathrm{~s}, 6 \mathrm{H}, \mathrm{NCH}_{3}\right), 1.60(\mathrm{t}$, $\left.6 \mathrm{H}, J_{\mathrm{HH}}=7.3 \mathrm{~Hz}, \mathrm{NCH}_{2} \mathrm{CH}_{3}\right) .{ }^{13} \mathrm{C}\left\{{ }^{1} \mathrm{H}\right\} \mathrm{NMR}\left(\mathrm{CD}_{3} \mathrm{CN}, 100 \mathrm{MHz}\right)$ : $\delta$ 140.3 $\left(\mathrm{C}_{\mathrm{trz}}\right), 130.9\left(\mathrm{C}_{\mathrm{trz}}-\mathrm{H}\right), 61.4\left(\mathrm{OCH}_{2}\right), 50.5\left(\mathrm{NCH}_{2}\right), 39.8$ $\left(\mathrm{NCH}_{3}\right), 14.7\left(\mathrm{NCH}_{2} \mathrm{CH}_{3}\right)$. ESI-MS $(\mathrm{m} / \mathrm{z})$ : 133.0876 , calcd for $\left[\mathrm{C}_{12} \mathrm{H}_{22} \mathrm{~N}_{6} \mathrm{O}\right]^{2+}$ 133.0928. Anal calcd for $\mathrm{C}_{12} \mathrm{H}_{22} \mathrm{~N}_{6} \mathrm{I}_{2} \mathrm{O}$ (520.15): C, 27.71; H, 4.26; N, 16.16\%. Found: C, 27.74; H, 4.06; N, $15.93 \%$.

Synthesis of $6 \mathrm{~b}(\mathrm{I})$. Compound $4 \mathrm{~b}(0.59 \mathrm{~g}, 1.78 \mathrm{mmol})$ and MeI $(0.44 \mathrm{~mL}, 7.10 \mathrm{mmol})$ were refluxed in MeCN for $20 \mathrm{~h}$. After purification according to the general procedure, the 
product was obtained as a white solid ( $0.84 \mathrm{~g}, 77 \%)$, which was recrystallized by slow diffusion of $\mathrm{Et}_{2} \mathrm{O}$ into an MeCN solution of the ditriazolium salt. ${ }^{1} \mathrm{H}$ NMR $\left(\left(\mathrm{CD}_{3}\right)_{2} \mathrm{SO}, 400 \mathrm{MHz}\right): \delta 9.62$ (s, 2H, $\mathrm{H}_{\text {trz }}$ ), 8.04-8.00 (m, 4H, $\left.\mathrm{H}_{\text {ortho }}\right)$, 7.78-7.74 (m, 6H, $\mathrm{H}_{\mathrm{Ph}}$ ), $5.12\left(\mathrm{~s}, \quad 4 \mathrm{H}, \mathrm{OCH}_{2}\right), 4.43\left(\mathrm{~s}, \quad 6 \mathrm{H}, \mathrm{NCH}_{3}\right) .{ }^{13} \mathrm{C}\left\{{ }^{1} \mathrm{H}\right\} \quad \mathrm{NMR}$ $\left(\left(\mathrm{CD}_{3}\right)_{2} \mathrm{SO}, 100 \mathrm{MHz}\right): \delta$ 140.3( $\left.\mathrm{C}_{\text {trz }}\right), 134.8\left(\mathrm{C}_{\text {ipso }}\right) 132.0\left(\mathrm{C}_{\text {para }}\right)$, $130.6\left(\mathrm{C}_{\text {meta }}\right), 128.6\left(\mathrm{C}_{\text {trz }}-\mathrm{H}\right), 121.7\left(\mathrm{C}_{\text {ortho }}\right), 60.1\left(\mathrm{OCH}_{2}\right), 38.9$ $\left(\mathrm{NCH}_{3}\right)$. ESI-MS $(\mathrm{m} / \mathrm{z}):$ 180.0915, calcd for $\left[\mathrm{C}_{20} \mathrm{H}_{22} \mathrm{~N}_{6} \mathrm{O}\right]^{2+}$ 180.0928. Anal calcd for $\mathrm{C}_{20} \mathrm{H}_{22} \mathrm{~N}_{6} \mathrm{I}_{2} \mathrm{O}$ (615.99): C, 38.98; H, 3.60 ; N, 13.64\%. Found: C, 38.88; H, 3.37; N, 13.52\%.

Synthesis of $6 \mathbf{c}(\mathrm{I})$. Compound $4 \mathrm{c}(0.38 \mathrm{~g}, 0.91 \mathrm{mmol})$ and MeI $(0.12 \mathrm{~mL}, 2.00 \mathrm{mmol})$ were refluxed for 2 days. After purification (see general procedure), the product was obtained as an off-white solid $(0.44 \mathrm{~g}, 69 \%)$. Subsequent recrystallization from $\mathrm{MeCN} / \mathrm{Et}_{2} \mathrm{O}$ yielded pure compound $6 \mathbf{c}(\mathrm{I}) .{ }^{1} \mathrm{H} \mathrm{NMR}\left(\mathrm{CD}_{3} \mathrm{CN}\right.$, $400 \mathrm{MHz}): \delta 8.89\left(\mathrm{~s}, 2 \mathrm{H}, \mathrm{H}_{\mathrm{trz}}\right), 7.17\left(\mathrm{~s}, 4 \mathrm{H}, \mathrm{H}_{\mathrm{Mes}}\right), 5.14(\mathrm{~s}, 4 \mathrm{H}$, $\left.\mathrm{OCH}_{2}\right), 4.39$ (s, 6H, $\left.\mathrm{NCH}_{3}\right), 2.38$ (s, $\left.\mathrm{CH}_{3 \text {-para }}\right), 2.09\left(\mathrm{CH}_{3 \text {-ortho }}\right)$. ${ }^{13} \mathrm{C}\left\{{ }^{1} \mathrm{H}\right\}$ NMR (CD $\left.{ }_{3} \mathrm{CN}, 100 \mathrm{MHz}\right): \delta 143.8\left(\mathrm{C}_{\text {para }}\right), 141.5\left(\mathrm{C}_{\text {trz }}\right)$, 135.6 ( $\left.\mathrm{C}_{\text {ortho }}\right), 133.0\left(\mathrm{C}_{\text {trz }}-\mathrm{H}\right), 131$ (broad, $\left.\mathrm{C}_{\text {ipso }}\right), 130.7\left(\mathrm{C}_{\text {meta }}\right)$, $62.1\left(\mathrm{OCH}_{2}\right), 40.5\left(\mathrm{NCH}_{3}\right), 21.2\left(\mathrm{CH}_{3 \text {-para }}\right), 17.6\left(\mathrm{CH}_{3 \text {-ortho }}\right)$. ESI-MS (m/z): 222.1308, calcd for $\left[\mathrm{C}_{26} \mathrm{H}_{34} \mathrm{~N}_{6} \mathrm{O}\right]^{2+}$ 223.1397. Anal calcd for $\mathrm{C}_{26} \mathrm{H}_{34} \mathrm{~N}_{6} \mathrm{I}_{2} \mathrm{O}(700.40) \times 0.5 \mathrm{Et}_{2} \mathrm{O}: \mathrm{C}, 45.60 ; \mathrm{H}, 5.33 ; \mathrm{N}$, $11.40 \%$. Found: C, 45.94; H, 4.93; N, 11.66\%.

\section{General procedure for halide exchange and formation of ditriazolium salts $5\left(\mathrm{BF}_{4}\right)$ and $6\left(\mathrm{BF}_{4}\right)$}

The ditriazolium iodide was suspended in MeCN $(10 \mathrm{~mL})$ and $\mathrm{AgBF}_{4}$ (2 mol equiv.) was added. The reaction mixture was stirred at room temperature for a set time. The crude reaction mixture was filtered through a short pad of Celite and evaporated to dryness.

Synthesis of $\mathbf{5 a}\left(\mathbf{B F}_{4}\right)$. According to the general procedure from $5 \mathrm{a}(\mathrm{I})(0.22 \mathrm{~g}, 0.42 \mathrm{mmol})$ and $\mathrm{AgBF}_{4}(0.18 \mathrm{~g}, 0.93 \mathrm{mmol})$ for $16 \mathrm{~h}$, the product was obtained as a waxy yellow solid (0.182 g, quantitative). ${ }^{1} \mathrm{H}$ NMR $\left(\mathrm{CD}_{3} \mathrm{CN}, 400 \mathrm{MHz}\right): \delta 8.28$ (s, $\left.2 \mathrm{H}, \mathrm{H}_{\text {trz }}\right), 4.54\left(\mathrm{q}, 4 \mathrm{H},{ }^{3} \mathrm{~J}_{\mathrm{HH}}=7.3 \mathrm{~Hz}, \mathrm{NCH}_{2}\right), 4.13(\mathrm{~s}, 6 \mathrm{H}$, $\mathrm{NCH}_{3}$ ), $2.93\left(\mathrm{t}, 4 \mathrm{H},{ }^{3} \mathrm{~J}_{\mathrm{HH}}=7.8 \mathrm{~Hz}, \mathrm{C}_{\mathrm{trz}} \mathrm{CH}_{2} \mathrm{CH}_{2}\right.$ ), 2.11 (quintet, $\left.2 \mathrm{H},{ }^{3} J_{\mathrm{HH}}=7.8 \mathrm{~Hz}, \mathrm{C}_{\mathrm{trz}} \mathrm{CH}_{2} \mathrm{CH}_{2}\right), 1.56\left(\mathrm{t}, 6 \mathrm{H},{ }^{3} J_{\mathrm{HH}}=7.3 \mathrm{~Hz}\right.$, $\left.\mathrm{NCH}_{2} \mathrm{CH}_{3}\right) .{ }^{13} \mathrm{C}\left\{{ }^{1} \mathrm{H}\right\} \operatorname{NMR}\left(\mathrm{CD}_{3} \mathrm{CN}, 100 \mathrm{MHz}\right): \delta 144.2\left(\mathrm{C}_{\text {trz }}\right)$, $128.5\left(\mathrm{C}_{\mathrm{trz}}-\mathrm{H}\right), 50.0\left(\mathrm{NCH}_{2}\right), 38.1\left(\mathrm{NCH}_{3}\right), 24.7\left(\mathrm{C}_{\mathrm{trz}} \mathrm{CH}_{2} \mathrm{CH}_{2}\right)$, $22.7\left(\mathrm{C}_{\mathrm{trz}} \mathrm{CH}_{2} \mathrm{CH}_{2}\right), 14.4\left(\mathrm{NCH}_{2} \mathrm{CH}_{3}\right)$. ESI-MS (m/z): 132.0949, calcd for $\left[\mathrm{C}_{13} \mathrm{H}_{24} \mathrm{~N}_{6}\right]$ 132.1031. The high viscosity of the product precluded removing of all solvent for satisfactory microanalysis even after repeated precipitations, irrespective of the solvent combinations used (see also ESI $\dagger$ ).

Synthesis of $\mathbf{5 b}\left(\mathbf{B F}_{4}\right)$. According to the general procedure from $5 \mathbf{b}(\mathbf{I})(110 \mathrm{mg}, 0.179 \mathrm{mmol})$ and $\mathrm{AgBF}_{4}(70 \mathrm{mg}$, $0.358 \mathrm{mmol}$ ) for $1 \mathrm{~h}$, the product was obtained as an off-white solid (96 mg, quantitative). Recrystallization from $\mathrm{MeCN} / \mathrm{Et}_{2} \mathrm{O}$ gave microanalytically pure material by slow diffusion of solution of the compound. ${ }^{1} \mathrm{H}$ NMR $\left(\mathrm{CD}_{3} \mathrm{CN}, 400 \mathrm{MHz}\right): \delta 8.77$ (s, $\left.2 \mathrm{H}, \mathrm{H}_{\mathrm{trz}}\right)$, 7.90-7.87 (m, 4H, $\left.\mathrm{H}_{\text {ortho }}\right)$, 7.74-7.71 (m, 6H, $\mathrm{H}_{\mathrm{Ph}}$ ), $4.28\left(\mathrm{~s}, 6 \mathrm{H}, \mathrm{NCH}_{3}\right), 3.08\left(\mathrm{t}, 4 \mathrm{H},{ }^{3} J_{\mathrm{HH}}=7.7 \mathrm{~Hz}, \mathrm{C}_{\mathrm{trz}} \mathrm{CH}_{2}\right), 2.30$ (quintet, $\left.2 \mathrm{H},{ }^{3} J_{\mathrm{HH}}=7.7 \mathrm{~Hz}, \mathrm{CCH}_{2} \mathrm{CH}_{2}\right) \cdot{ }^{13} \mathrm{C}\left\{{ }^{1} \mathrm{H}\right\} \mathrm{NMR}\left(\mathrm{CD}_{3} \mathrm{CN}\right.$, $100 \mathrm{MHz}): \delta 145.2\left(\mathrm{C}_{\text {trz }}\right), 136.0\left(\mathrm{C}_{\text {ipso }}\right), 132.9$ ( $\left.\mathrm{C}_{\text {para }}\right), 131.5$ $\left(\mathrm{C}_{\text {meta }}\right), \quad 127.5\left(\mathrm{C}_{\mathrm{trz}}-\mathrm{H}\right), 122.5 \quad\left(\mathrm{C}_{\text {ortho }}\right), 38.8 \quad\left(\mathrm{NCH}_{3}\right), 24.6$
$\left(\mathrm{C}_{\mathrm{trz}} \mathrm{CH}_{2} \mathrm{CH}_{2}\right), 22.9\left(\mathrm{C}_{\mathrm{trz}} \mathrm{CH}_{2}\right)$. ESI-MS $(\mathrm{m} / \mathrm{z}): 180.1006$, calcd for $\left[\mathrm{C}_{21} \mathrm{H}_{24} \mathrm{~N}_{6}\right]^{2+}$ 180.1031. Anal calcd for $\mathrm{C}_{21} \mathrm{H}_{24} \mathrm{~B}_{2} \mathrm{~F}_{8} \mathrm{~N}_{6}$ (534.06): C, 47.23; H, 4.53; N, 15.74\%. Found: C, 47.12; H, 4.27; N, $15.67 \%$.

Synthesis of $5 \mathbf{c}\left(\mathbf{B F}_{4}\right)$. According to the general procedure from $5 \mathbf{c}(\mathrm{I})(0.28 \mathrm{~g}, 0.4 \mathrm{mmol})$ and $\mathrm{AgBF}_{4}(0.17 \mathrm{~g}, 0.88 \mathrm{mmol})$ for $16 \mathrm{~h}$, the product was obtained as an off-white solid (0.25 g, quantitative). A microanalytically pure sample was obtained by slow diffusion of $\mathrm{Et}_{2} \mathrm{O}$ into an MeCN solution of the compound. ${ }^{1} \mathrm{H}$ NMR $\left(\mathrm{CD}_{3} \mathrm{CN}, 400 \mathrm{MHz}\right): \delta 8.42(\mathrm{~s}, 2 \mathrm{H}$, $\left.\mathrm{H}_{\text {trz }}\right), 7.17\left(\mathrm{~s}, 4 \mathrm{H}, \mathrm{H}_{\mathrm{Mes}}\right), 4.28\left(\mathrm{~s}, 6 \mathrm{H}, \mathrm{NCH}_{3}\right), 3.09\left(\mathrm{t}, 4 \mathrm{H},{ }^{3} \mathrm{~J}_{\mathrm{HH}}=\right.$ $7.9 \mathrm{~Hz}, \mathrm{C}_{\text {trz }} \mathrm{CH}_{2}$ ), 2.39 (s, 6H, $\mathrm{CH}_{3 \text {-para }}$ ), 2.31 (quintet, $2 \mathrm{H},{ }^{3} \mathrm{~J}_{\mathrm{HH}}$ $\left.=7.9 \mathrm{~Hz}, \mathrm{CCH}_{2} \mathrm{CH}_{2}\right), 2.06\left(\mathrm{~s}, 12 \mathrm{H}, \mathrm{CH}_{3 \text {-ortho }}\right) .{ }^{13} \mathrm{C}\left\{{ }^{1} \mathrm{H}\right\} \mathrm{NMR}$ $\left(\mathrm{CD}_{3} \mathrm{CN}, 100 \mathrm{MHz}\right): \delta 145.3\left(\mathrm{C}_{\text {trz }}\right), 143.5\left(\mathrm{C}_{\text {para }}\right), 135.6\left(\mathrm{C}_{\text {ortho }}\right)$, $132.3\left(\mathrm{C}_{\text {ipso }}\right), 131.1\left(\mathrm{C}_{\mathrm{trz}}-\mathrm{H}\right), 130.5\left(\mathrm{C}_{\text {meta }}\right), 38.9\left(\mathrm{NCH}_{3}\right), 24.2$ $\left(\mathrm{C}_{\mathrm{trz}} \mathrm{CH}_{2} \mathrm{CH}_{2}\right), 23.2\left(\mathrm{C}_{\mathrm{trz}} \mathrm{CH}_{2}\right), 21.1$ ( $\left.\mathrm{CH}_{3 \text {-para }}\right), 17.1$ ( $\left.\mathrm{CH}_{3 \text {-ortho }}\right)$. ESI-MS $(m / z): 222.1485$, calcd for $\left[\mathrm{C}_{27} \mathrm{H}_{36} \mathrm{~N}_{6}\right]^{+}$222.1500. Anal calcd for $\mathrm{C}_{27} \mathrm{H}_{36} \mathrm{~B}_{2} \mathrm{~F}_{8} \mathrm{~N}_{6}$ (618.22): C, 52.45; H, 5.87; N, 13.59\%. Found: C, 52.38; H, 5.81; N, 13.56\%.

Synthesis of $6 \mathrm{a}\left(\mathrm{BF}_{4}\right)$. According to the general procedure from the triazolium iodide $6 \mathrm{a}(\mathrm{I})(0.50 \mathrm{~g}, 0.96 \mathrm{mmol})$ and $\mathrm{AgBF}_{4}$ $(0.41 \mathrm{~g}, 2.11 \mathrm{mmol})$ for $2 \mathrm{~h}$, the product was obtained as an off-white solid (0.42 g, quantitative). Microanalytically pure material was obtained by slow diffusion of $\mathrm{Et}_{2} \mathrm{O}$ into an MeCN solution of the ditriazolium salt. ${ }^{1} \mathrm{H}$ NMR $\left(\mathrm{CD}_{3} \mathrm{CN}, 400 \mathrm{MHz}\right)$ : $\delta 8.44\left(\mathrm{~s}, 2 \mathrm{H}, \mathrm{H}_{\mathrm{trz}}\right), 4.86\left(\mathrm{~s}, 4 \mathrm{H}, \mathrm{OCH}_{2}\right), 4.58$ (q, $4 \mathrm{H}, J_{\mathrm{HH}}=7.3$ $\left.\mathrm{Hz}, \mathrm{NCH}_{2}\right), 4.19\left(\mathrm{~s}, 6 \mathrm{H}, \mathrm{NCH}_{3}\right), 1.57\left(\mathrm{t}, 6 \mathrm{H}, J_{\mathrm{HH}}=7.3 \mathrm{~Hz}\right.$, $\left.\mathrm{NCH}_{2} \mathrm{CH}_{3}\right) .{ }^{13} \mathrm{C}\left\{{ }^{1} \mathrm{H}\right\}$ NMR $\left(\mathrm{CD}_{3} \mathrm{CN}, 100 \mathrm{MHz}\right): \delta 140.2\left(\mathrm{C}_{\text {trz }}\right)$, $130.1\left(\mathrm{C}_{\mathrm{trz}}-\mathrm{H}\right), 60.8\left(\mathrm{OCH}_{2}\right), 50.3\left(\mathrm{NCH}_{2}\right), 39.0\left(\mathrm{NCH}_{3}\right), 14.4$ $\left(\mathrm{NCH}_{2} \mathrm{CH}_{3}\right)$. ESI-MS $(\mathrm{m} / \mathrm{z}): 133.0871$, calcd for $\left[\mathrm{C}_{12} \mathrm{H}_{22} \mathrm{~N}_{6} \mathrm{O}\right]^{2+}$ 133.0928. Anal calcd for $\mathrm{C}_{12} \mathrm{H}_{22} \mathrm{~N}_{6} \mathrm{~B}_{2} \mathrm{~F}_{8} \mathrm{O}(439.95) \times 0.2 \mathrm{H}_{2} \mathrm{O}: \mathrm{C}$, 32.49; H, 5.09; N, 18.95\%. Found: C, 32.49; H, 4.75; N, 18.59\%.

Synthesis of $6 \mathbf{b}\left(\mathbf{B F}_{4}\right)$. According to the general procedure from the triazolium iodide $6 \mathbf{b}(\mathbf{I})(0.43 \mathrm{~g}, 0.70 \mathrm{mmol})$ and $\mathrm{AgBF}_{4}(0.41 \mathrm{~g}, 2.11 \mathrm{mmol})$ for $1 \mathrm{~h}$, the product was obtained as an off-white solid ( $0.38 \mathrm{~g}$, quantitative). Microanalytically pure material was obtained by slow diffusion of $\mathrm{Et}_{2} \mathrm{O}$ into an MeCN solution of the compound. ${ }^{1} \mathrm{H} \mathrm{NMR}\left(\mathrm{CD}_{3} \mathrm{CN}, 400 \mathrm{MHz}\right): \delta 8.92$ (s, 2H, $\mathrm{H}_{\text {trz }}$ ), 7.91-7.87 (m, 4H, $\left.\mathrm{H}_{\text {ortho }}\right)$, 7.74-7.70 (m, 6H, $\mathrm{H}_{\mathrm{Ph}}$ ), $5.02\left(\mathrm{~s}, 4 \mathrm{H}, \mathrm{OCH}_{2}\right), 4.36\left(\mathrm{~s}, 6 \mathrm{H}, \mathrm{NCH}_{3}\right) .{ }^{13} \mathrm{C}\left\{{ }^{1} \mathrm{H}\right\} \mathrm{NMR}\left(\mathrm{CD}_{3} \mathrm{CN}\right.$, $100 \mathrm{MHz}): \delta 141.2\left(\mathrm{C}_{\text {trz }}\right), 135.9$ ( $\left.\mathrm{C}_{\text {ipso }}\right) 133.0$ ( $\left.\mathrm{C}_{\text {para }}\right), 131.4$ $\left(\mathrm{C}_{\text {meta }}\right), 129.1\left(\mathrm{C}_{\mathrm{trz}}-\mathrm{H}\right), 122.7\left(\mathrm{C}_{\text {ortho }}\right), 61.0\left(\mathrm{OCH}_{3}\right), 39.6\left(\mathrm{NCH}_{3}\right)$. ESI-MS (m/z): 180.0900 , calcd for $\left[\mathrm{C}_{20} \mathrm{H}_{22} \mathrm{~N}_{6} \mathrm{O}\right]^{2+}$ 180.0928. Anal calcd for $\mathrm{C}_{20} \mathrm{H}_{22} \mathrm{~N}_{6} \mathrm{~B}_{2} \mathrm{~F}_{4} \mathrm{O}$ (536.04): C, 44.81; H, 4.14; N, 15.68\%. Found: C, 44.50; H, 3.93; N, 15.48\%.

Synthesis of $6 \mathbf{c}\left(\mathrm{BF}_{4}\right)$. According to the general procedure from the triazolium iodide $6 \mathrm{c}(\mathrm{I})(0.40 \mathrm{~g}, 0.57 \mathrm{mmol})$ and $\mathrm{AgBF}_{4}$ $(0.22 \mathrm{~g}, 1.14 \mathrm{mmol})$ for $16 \mathrm{~h}$, the product was obtained as an off-white solid (0.35 g, quantitative). Microanalytically pure material was obtained by slow diffusion of $\mathrm{Et}_{2} \mathrm{O}$ into an MeCN solution of the compound. ${ }^{1} \mathrm{H} \mathrm{NMR}\left(\mathrm{CD}_{3} \mathrm{CN}, 400 \mathrm{MHz}\right): \delta 8.62$ $\left(\mathrm{s}, 2 \mathrm{H}, \mathrm{H}_{\mathrm{trz}}\right), 7.16\left(\mathrm{~s}, 4 \mathrm{H}, \mathrm{H}_{\mathrm{Mes}}\right), 5.06\left(\mathrm{~s}, 4 \mathrm{H}, \mathrm{OCH}_{2}\right), 4.36(\mathrm{~s}, 6 \mathrm{H}$, $\left.\mathrm{NCH}_{3}\right), 2.37$ ( $\left.\mathrm{CH}_{3 \text {-para }}\right), 2.05\left(\mathrm{CH}_{3 \text {-ortho }}\right) .{ }^{13} \mathrm{C}\left\{{ }^{1} \mathrm{H}\right\} \mathrm{NMR}\left(\mathrm{CD}_{3} \mathrm{CN}\right.$, $100 \mathrm{MHz}): \delta 143.6\left(\mathrm{C}_{\text {para }}\right), 141.4\left(\mathrm{C}_{\mathrm{trz}}\right), 135.6\left(\mathrm{C}_{\text {ortho }}\right) 132.6\left(\mathrm{C}_{\mathrm{trz}}-\mathrm{H}\right)$, $132.1\left(\mathrm{C}_{\text {ipso }}\right), 130.5\left(\mathrm{C}_{\text {meta }}\right), 61.6\left(\mathrm{OCH}_{2}\right), 39.8\left(\mathrm{NCH}_{3}\right), 21.1$ $\left(\mathrm{CH}_{3 \text {-para }}\right), 17.1$ ( $\left.\mathrm{CH}_{3 \text {-ortho }}\right)$. ESI-MS $(\mathrm{m} / \mathrm{z}): 223.1395$, calcd for 
$\left[\mathrm{C}_{26} \mathrm{H}_{34} \mathrm{~N}_{6} \mathrm{O}\right]^{2+}$ 223.1397. Anal calcd for $\mathrm{C}_{26} \mathrm{H}_{34} \mathrm{~N}_{6} \mathrm{~B}_{2} \mathrm{~F}_{8} \mathrm{O}$ $(620.21) \times 0.5 \mathrm{CH}_{2} \mathrm{Cl}_{2}$ : C, 47.87; H, 5.14; N, 12.61\%. Found: C, 48.03; H, 5.32; N, 12.68\%.

Synthesis of 7. Triazolium salt $\mathbf{5 a}\left(\mathbf{B F}_{4}\right)(68 \mathrm{mg}, 0.16 \mathrm{mmol})$, $\mathrm{Me}_{4} \mathrm{NCl}$ (296 mg, $\left.1.55 \mathrm{mmol}\right)$ and $\mathrm{Ag}_{2} \mathrm{O}(72 \mathrm{mg}, 0.31 \mathrm{mmol})$ were refluxed in $\mathrm{MeCN}(10 \mathrm{~mL})$ for $1 \mathrm{~h}$. After cooling to room temperature the suspension was filtered through Celite and the solvent was removed under reduced pressure. The residue was dissolved in $\mathrm{CH}_{2} \mathrm{Cl}_{2}(10 \mathrm{~mL})$ and filtered through cotton to remove $\mathrm{Me}_{4} \mathrm{NCl}$ by washing with $\mathrm{CH}_{2} \mathrm{Cl}_{2}(2 \times 10 \mathrm{~mL})$. Then $\left[\mathrm{Cp}^{*} \mathrm{RhCl}_{2}\right]_{2}$ (47 mg, $0.076 \mathrm{mmol}$ ) was dissolved in $\mathrm{CH}_{2} \mathrm{Cl}_{2}$ $(10 \mathrm{~mL})$ and the solution was frozen. The silver triazolylidene solution $(10 \mathrm{~mL})$ was added dropwise to the frozen rhodium solution and the solution was allowed to warm to room temperature. The mixture was stirred at room temperature for $1 \mathrm{~h}$. After filtration through Celite and removal of the solvent under reduced pressure the residue was purified by column chromatography ( $\mathrm{SiO}_{2} ; \mathrm{CH}_{2} \mathrm{Cl}_{2}$ then $\mathrm{CH}_{2} \mathrm{Cl}_{2} / \mathrm{CH}_{3} \mathrm{OH}, 9: 1$ ) yielding the title complex as an orange solid (75 $\mathrm{mg}, 85 \%$ ). Crystals of 7 suitable for X-ray diffraction studies were obtained by diffusion of pentane into a $\mathrm{CH}_{2} \mathrm{Cl}_{2} / \mathrm{MeCN}(20: 1)$ solution of the complex.

${ }^{1} \mathrm{H}$ NMR $\left(\mathrm{CD}_{3} \mathrm{CN}, 400 \mathrm{MHz}\right): \delta 4.81,4.42\left(2 \times \mathrm{dq}, 2 \mathrm{H},{ }^{2} J_{\mathrm{HH}}=\right.$ $\left.12.9 \mathrm{~Hz},{ }^{3} J_{\mathrm{HH}}=7.2 \mathrm{~Hz}, \mathrm{NCH}_{2}\right), 4.06\left(\mathrm{~s}, 6 \mathrm{H}, \mathrm{NCH}_{3}\right), 2.70,2.40(2$ $\times \mathrm{ddd}, 2 \mathrm{H},{ }^{2} J_{\mathrm{HH}}=14.9 \mathrm{~Hz},{ }^{3} J_{\mathrm{HH}}=8.6 \mathrm{~Hz},{ }^{3} J_{\mathrm{HH}}=4.6 \mathrm{~Hz}$, $\mathrm{C}_{\text {trz }} \mathrm{CH}_{2}$ ), 1.88-1.69 (m, 2H, $\left.\mathrm{CCH}_{2} \mathrm{CH}_{2}\right) 1.45\left(\mathrm{t}, 6 \mathrm{H},{ }^{3} J_{\mathrm{HH}}=7.1\right.$ $\left.\mathrm{Hz}, \mathrm{NCH}_{2} \mathrm{CH}_{3}\right), 1.43$ (s, $\left.15 \mathrm{H}, \mathrm{Cp}-\mathrm{CH}_{3}\right) .{ }^{13} \mathrm{C}\left\{{ }^{1} \mathrm{H}\right\} \mathrm{NMR}\left(\mathrm{CD}_{3} \mathrm{CN}\right.$, $100 \mathrm{MHz}): \delta 154.4\left(\mathrm{~d},{ }^{1} J_{\mathrm{CRh}}=50.3 \mathrm{~Hz}, \mathrm{C}_{\mathrm{trz}}-\mathrm{Rh}\right), 145.5\left(\mathrm{~d},{ }^{2} J_{\mathrm{CRh}}\right.$ $\left.=3.3 \mathrm{~Hz}, \mathrm{C}_{\mathrm{trz}}\right), 100.2\left(\mathrm{~d},{ }^{1} J_{\mathrm{CRh}}=5.2 \mathrm{~Hz}, \mathrm{C}_{\mathrm{Cp}}\right), 50.2\left(\mathrm{NCH}_{2}\right), 37.5$ $\left(\mathrm{NCH}_{3}\right), 24.4\left(\mathrm{CCH}_{2} \mathrm{CH}_{2}\right), 22.5\left(\mathrm{C}_{\mathrm{trz}} \mathrm{CH}_{2}\right), 17.0\left(\mathrm{NCH}_{2} \mathrm{CH}_{3}\right), 9.5$ $\left(\mathrm{Cp}-\mathrm{CH}_{3}\right)$. ESI-MS $(\mathrm{m} / \mathrm{z}): 535.1844$, calcd for $\left[\mathrm{C}_{23} \mathrm{H}_{37} \mathrm{~N}_{6} \mathrm{RhCl}\right]^{+}$ 535.1823. Anal calcd for $\mathrm{C}_{23} \mathrm{H}_{37} \mathrm{~B}_{0.21} \mathrm{~F}_{0.84} \mathrm{Cl}_{1.79} \mathrm{~N}_{6} \mathrm{Rh}(582.17) \times$ $0.3 \mathrm{CH}_{2} \mathrm{Cl}_{2}$ : C, 46.05; H, 6.24; N, 13.83\%. Found: C, 46.44; H, $5.85 ; \mathrm{N}, 13.44 \%$.

Synthesis of $\mathbf{8}$. The triazolium salt $\mathbf{5 b}\left(\mathbf{B F}_{\mathbf{4}}\right)$ (177 $\mathrm{mg}$, $0.33 \mathrm{mmol})$ and $\mathrm{Ag}_{2} \mathrm{O}(298 \mathrm{mg}, 1.29 \mathrm{mmol})$ were stirred at room temperature in MeCN $(100 \mathrm{~mL})$ for 2 days under exclusion of light. The mixture was filtered through Celite and all volatiles were removed under reduced pressure. The residual crystalline white solid was suspended in $\mathrm{CH}_{2} \mathrm{Cl}_{2}(200 \mathrm{~mL})$ and $\left[\mathrm{Cp}^{*} \mathrm{RhCl}_{2}\right]_{2}$ (50 mg, $0.08 \mathrm{mmol}$ ) was added. The mixture was stirred for 10 minutes and filtered through Celite. After solvent evaporation, the residue was purified by column chromatography $\left(\mathrm{SiO}_{2} ; \mathrm{CH}_{2} \mathrm{Cl}_{2}\right.$ then $\mathrm{CH}_{2} \mathrm{Cl}_{2}$ /acetone, $\left.1: 1\right)$ yielding the title complex as a yellow solid (38 mg, 35\%). Crystals of 8 suitable for X-ray diffraction studies were obtained by diffusion of $\mathrm{Et}_{2} \mathrm{O}$ into a $\mathrm{CH}_{2} \mathrm{Cl}_{2}$ solution of the complex.

${ }^{1} \mathrm{H}$ NMR ( $\left.\mathrm{CD}_{3} \mathrm{CN}, 400 \mathrm{MHz}\right): \delta 7.47\left(\mathrm{tt}, 1 \mathrm{H},{ }^{3} J_{\mathrm{HH}}=7.5 \mathrm{~Hz}\right.$, $\left.{ }^{4} J_{\mathrm{HH}}=1.2 \mathrm{~Hz}, \mathrm{H}_{\mathrm{Ph}}\right), 7.37\left(\mathrm{dd}, 1 \mathrm{H},{ }^{3} J_{\mathrm{HH}}=7.8 \mathrm{~Hz},{ }^{4} J_{\mathrm{HH}}=1.3 \mathrm{~Hz}\right.$, $\left.\mathrm{H}_{\mathrm{Ph}-\mathrm{Rh}}\right), 7.28\left(\mathrm{t},{ }^{3} \mathrm{~J}_{\mathrm{HH}}=7.9 \mathrm{~Hz}, 2 \mathrm{H}, \mathrm{H}_{\mathrm{Ph}}\right), 6.82\left(\mathrm{ddd}, 1 \mathrm{H},{ }^{3} J_{\mathrm{HH}}=\right.$ $\left.7.8 \mathrm{~Hz},{ }^{3} J_{\mathrm{HH}}=7.2 \mathrm{~Hz},{ }^{4} J_{\mathrm{HH}}=1.3 \mathrm{~Hz}, \mathrm{H}_{\mathrm{Ph}-\mathrm{Rh}}\right), 6.64\left(\mathrm{~d}, 2 \mathrm{H},{ }^{3} J_{\mathrm{HH}}\right.$ $\left.=7.3 \mathrm{~Hz}, \mathrm{H}_{\mathrm{Ph}}\right), 6.59\left(\mathrm{~d}, 1 \mathrm{H},{ }^{3} J_{\mathrm{HH}}=7.7 \mathrm{~Hz}, \mathrm{H}_{\mathrm{Ph}-\mathrm{Rh}}\right), 6.46(\mathrm{dt}, 1 \mathrm{H}$, $\left.{ }^{3} J_{\mathrm{HH}}=7.5 \mathrm{~Hz},{ }^{4} J_{\mathrm{HH}}=1.4 \mathrm{~Hz}, \mathrm{H}_{\mathrm{Ph}-\mathrm{Rh}}\right), 4.01,3.86(2 \times \mathrm{s}, 3 \mathrm{H}$, $\left.\mathrm{NCH}_{3}\right), 3.32-3.11\left(\mathrm{~m}, 4 \mathrm{H}, \mathrm{C}_{\mathrm{trz}} \mathrm{CH}_{2}\right), 2.38-2.29(\mathrm{~m}, 1 \mathrm{H}$, $\left.\mathrm{C}_{\mathrm{trz}} \mathrm{CH}_{2} \mathrm{CH}_{2}\right), 1.76\left(\mathrm{~s}, 15 \mathrm{H}, \mathrm{Cp}-\mathrm{CH}_{3}\right), 1.68-1.56(\mathrm{~m}, 1 \mathrm{H}$, $\left.\mathrm{C}_{\text {trz }} \mathrm{CH}_{2} \mathrm{CH}_{2}\right) .{ }^{13} \mathrm{C}\left\{{ }^{1} \mathrm{H}\right\}$ NMR $\left(\mathrm{CD}_{3} \mathrm{CN}, 100 \mathrm{MHz}\right): \delta 164.2(\mathrm{~d}$, $\left.{ }^{1} J_{\mathrm{CRh}}=47.0 \mathrm{~Hz}, \mathrm{C}_{\mathrm{trz}}-\mathrm{Rh}\right), 159.5\left(\mathrm{~d},{ }^{1} J_{\mathrm{CRh}}=36.2 \mathrm{~Hz}, \mathrm{C}_{\mathrm{Ph}}-\mathrm{Rh}\right)$, $158.2\left(\mathrm{~d},{ }^{1} J_{\mathrm{CRh}}=50.3 \mathrm{~Hz}, \mathrm{C}_{\mathrm{trz}}-\mathrm{Rh}\right), 149.6\left(\mathrm{~d},{ }^{2} J_{\mathrm{CRh}}=1.4 \mathrm{~Hz}\right.$, $\left.\mathrm{C}_{\text {trz }}\right), 146.2\left(\mathrm{~d},{ }^{2} J_{\mathrm{CRh}}=3.7 \mathrm{~Hz}, \mathrm{C}_{\mathrm{trz}}\right), 144.0\left(\mathrm{C}_{\mathrm{Ph}-\mathrm{Rh}}\right), 141.3\left(\mathrm{C}_{\mathrm{Ph}}\right)$, 139.6 ( $\left.\mathrm{C}_{\mathrm{Ph}-\mathrm{Rh}}\right), 130.4\left(\mathrm{C}_{\mathrm{Ph}}\right), 129.9\left(\mathrm{C}_{\mathrm{Ph}}\right), 127.9\left(\mathrm{~d},{ }^{3} J_{\mathrm{CRh}}=1.7 \mathrm{~Hz}\right.$, $\left.\mathrm{C}_{\mathrm{Ph}-\mathrm{Rh}}\right), 126.5\left(\mathrm{C}_{\mathrm{Ph}}\right), 122.5\left(\mathrm{C}_{\mathrm{Ph}-\mathrm{Rh}}\right), 113.4\left(\mathrm{~d},{ }^{3} J_{\mathrm{CRh}}=1.2 \mathrm{~Hz}\right.$, $\left.\mathrm{C}_{\mathrm{Ph}-\mathrm{Rh}}\right), 99.2\left(\mathrm{~d}, J=4.1 \mathrm{~Hz}, \mathrm{C}_{\mathrm{Cp}}\right), 37.1,37.0\left(2 \times \mathrm{NCH}_{3}\right), 26.4$ $\left(\mathrm{C}_{\mathrm{trz}} \mathrm{CH}_{2} \mathrm{CH}_{2}\right), 26.0,25.7\left(2 \times \mathrm{C}_{\mathrm{trz}} \mathrm{CH}_{2}\right), 10.7\left(\mathrm{Cp}-\mathrm{CH}_{3}\right)$. ESI-MS $(\mathrm{m} / \mathrm{z})$ : 595.2040, calcd for $\left[\mathrm{C}_{31} \mathrm{H}_{36} \mathrm{~N}_{6} \mathrm{Rh}\right]^{+}$595.2056. Anal calcd for $\mathrm{C}_{31} \mathrm{H}_{36} \mathrm{BF}_{4} \mathrm{~N}_{6} \mathrm{Rh}(595.56) \times 0.2 \mathrm{CH}_{2} \mathrm{Cl}_{2}: \mathrm{C}, 53.58 ; \mathrm{H}, 5.25 ; \mathrm{N}$, $12.02 \%$. Found: C, 53.69; H, 5.13; N, 11.95\%.

Synthesis of 9. The triazolium salt $\mathbf{6 b}\left(\mathbf{B F}_{4}\right)(0.20 \mathrm{~g}$, $0.37 \mathrm{mmol}), \mathrm{Ag}_{2} \mathrm{O}(0.35 \mathrm{~g}, 1.49 \mathrm{mmol})$, and $\mathrm{KCl}(0.28 \mathrm{~g}$, $3.73 \mathrm{mmol})$ were stirred at room temperature in $\mathrm{MeCN}(80 \mathrm{~mL})$ for 2 days under exclusion of light. The mixture was filtered through Celite and all volatiles were removed under reduced pressure. The resulting white solid was suspended in $\mathrm{CH}_{2} \mathrm{Cl}_{2}$ $(200 \mathrm{~mL})$ and cooled to $-30{ }^{\circ} \mathrm{C}$. Then, $\left[\mathrm{Cp}^{*} \mathrm{RhCl}_{2}\right]_{2}(0.12 \mathrm{~g}$, $0.19 \mathrm{mmol})$ in $\mathrm{CH}_{2} \mathrm{Cl}_{2}(5 \mathrm{~mL})$ was added dropwise while stirring. Stirring was continued for $2 \mathrm{~h}$ at $-30{ }^{\circ} \mathrm{C}$ and for $16 \mathrm{~h}$ at room temperature. After filtration through Celite, the crude product was purified by column chromatography $\left(\mathrm{SiO}_{2}\right.$; $\mathrm{CH}_{2} \mathrm{Cl}_{2}$ then $\mathrm{CH}_{2} \mathrm{Cl}_{2}$ /acetone, $9: 1$ ) yielding complex 9 as a pale yellow solid (93 mg, 36\%). Crystals suitable for X-ray diffraction studies were obtained by diffusion of $\mathrm{Et}_{2} \mathrm{O}$ into a $\mathrm{CH}_{2} \mathrm{Cl}_{2}$ solution of the complex.

${ }^{1} \mathrm{H}$ NMR $\left(\mathrm{CD}_{3} \mathrm{CN}, 400 \mathrm{MHz}\right): \delta 7.50\left(\mathrm{tt}, 1 \mathrm{H},{ }^{3} J_{\mathrm{HH}}=7.5 \mathrm{~Hz}\right.$, $\left.{ }^{4} J_{\mathrm{HH}}=1.2 \mathrm{~Hz}, \mathrm{H}_{\mathrm{Ph}}\right), 7.37\left(\mathrm{dd}, 1 \mathrm{H},{ }^{3} J_{\mathrm{HH}}=7.8 \mathrm{~Hz},{ }^{4} J_{\mathrm{HH}}=1.3 \mathrm{~Hz}\right.$, $\mathrm{H}_{\mathrm{Ph}}$ ), 7.34-7.29 (t, $\left.{ }^{3} \mathrm{~J}_{\mathrm{HH}}=8.0 \mathrm{~Hz}, 2 \mathrm{H}, \mathrm{H}_{\mathrm{Ph}}\right), 6.86\left(\mathrm{ddd}, 1 \mathrm{H},{ }^{3} J_{\mathrm{HH}}\right.$ $\left.=7.9 \mathrm{~Hz},{ }^{3} \mathrm{~J}_{\mathrm{HH}}=7.2 \mathrm{~Hz},{ }^{4} J_{\mathrm{HH}}=1.3 \mathrm{~Hz}, \mathrm{H}_{\mathrm{Ph}-\mathrm{Rh}}\right), 6.70(\mathrm{dd}, 2 \mathrm{H}$, $\left.{ }^{3} J_{\mathrm{HH}}=8.3 \mathrm{~Hz},{ }^{4} J_{\mathrm{HH}}=1.1 \mathrm{~Hz}, \mathrm{H}_{\mathrm{Ph}}\right), 6.57\left(\mathrm{~d}, 1 \mathrm{H},{ }^{3} J_{\mathrm{HH}}=7.7 \mathrm{~Hz}\right.$, $\left.\mathrm{H}_{\mathrm{Ph}-\mathrm{Rh}}\right), 6.50\left(\mathrm{dt}, 1 \mathrm{H},{ }^{3} J_{\mathrm{HH}}=7.2 \mathrm{~Hz},{ }^{4} J_{\mathrm{HH}}=1.4 \mathrm{~Hz}, \mathrm{H}_{\mathrm{Ph}-\mathrm{Rh}}\right)$, $5.12\left(\mathrm{~d}, 1 \mathrm{H},{ }^{2} \mathrm{~J}_{\mathrm{HH}}=14.7 \mathrm{~Hz}, \mathrm{OCH}_{2}\right), 5.10,4.99\left(2 \times \mathrm{d}, 1 \mathrm{H},{ }^{2} \mathrm{~J}_{\mathrm{HH}}=\right.$ $\left.14.9 \mathrm{~Hz}, \mathrm{OCH}_{2}\right), 4.96\left(\mathrm{~d}, 1 \mathrm{H},{ }^{2} J_{\mathrm{HH}}=14.7 \mathrm{~Hz}, \mathrm{OCH}_{2}\right), 4.08,3.95$ $\left(2 \times \mathrm{s}, 3 \mathrm{H}, \mathrm{NCH}_{3}\right), 1.75\left(\mathrm{~s}, 15 \mathrm{H}, \mathrm{Cp}-\mathrm{CH}_{3}\right) .{ }^{13} \mathrm{C}\left\{{ }^{1} \mathrm{H}\right\} \mathrm{NMR}$ $\left(\mathrm{CD}_{3} \mathrm{CN}, 100 \mathrm{MHz}\right): \delta 167.9\left(\mathrm{~d},{ }^{1} J_{\mathrm{CRh}}=46.9 \mathrm{~Hz}, \mathrm{C}_{\mathrm{trz}}-\mathrm{Rh}\right), 160$ $\left(\mathrm{C}_{\mathrm{trz}}-\mathrm{Rh}\right), 158.7\left(\mathrm{~d},{ }^{1} J_{\mathrm{CRh}}=46.9 \mathrm{~Hz}, \mathrm{C}_{\mathrm{Ph}}-\mathrm{Rh}\right), 147.1\left(\mathrm{~d},{ }^{2} J_{\mathrm{CRh}}=\right.$ $\left.1.3 \mathrm{~Hz}, \mathrm{C}_{\mathrm{trz}}\right), 144.1$ (d, $\left.{ }^{2} J_{\mathrm{CRh}}=3.8 \mathrm{~Hz}, \mathrm{C}_{\mathrm{trz}}\right), 144.0\left(\mathrm{C}_{\mathrm{Ph}-\mathrm{Rh}}\right), 140.9$ $\left(\mathrm{C}_{\mathrm{Ph}}\right), 139.5\left(\mathrm{C}_{\mathrm{Ph}-\mathrm{Rh}}\right), 130.7\left(\mathrm{C}_{\mathrm{Ph}}\right), 129.4\left(\mathrm{C}_{\mathrm{Ph}}\right), 128.0\left(\mathrm{~d},{ }^{3} J_{\mathrm{CRh}}=\right.$ $\left.1.6 \mathrm{~Hz}, \mathrm{C}_{\mathrm{Ph}-\mathrm{Rh}}\right), 126.6\left(\mathrm{C}_{\mathrm{Ph}}\right), 122.8\left(\mathrm{C}_{\mathrm{Ph}-\mathrm{Rh}}\right), 113.6\left(\mathrm{~d},{ }^{3} J_{\mathrm{CRh}}=1.3\right.$ $\left.\mathrm{Hz}, \mathrm{C}_{\mathrm{Ph}-\mathrm{Rh}}\right), 99.4$ (d, $\left.J=4.0 \mathrm{~Hz}, \mathrm{C}_{\mathrm{Cp}}\right), 65.3,64.8\left(2 \times \mathrm{OCH}_{2}\right)$, 37.4, $37.3\left(2 \times \mathrm{NCH}_{3}\right), 10.6\left(\mathrm{Cp}-\mathrm{CH}_{3}\right)$. ESI-MS (m/z): 597.1878, calcd for $\left[\mathrm{C}_{30} \mathrm{H}_{34} \mathrm{~N}_{6} \mathrm{ORh}\right]^{+}$597.1849. Anal calcd for $\mathrm{C}_{30} \mathrm{H}_{34} \mathrm{BF}_{4} \mathrm{~N}_{6} \mathrm{ORh}(684.34) \times 0.25 \mathrm{CH}_{2} \mathrm{Cl}_{2}: \mathrm{C}, 51.49 ; \mathrm{H}, 4.93 ; \mathrm{N}$, $11.91 \%$. Found: C, $51.53 ; \mathrm{H}, 4.88 ; \mathrm{N}, 11.84 \%$.

Synthesis of 10. According to the procedure described for the synthesis of $\mathbf{9}$, complex $\mathbf{1 0}$ was obtained from $\mathbf{6 b}\left(\mathbf{B F}_{\mathbf{4}}\right)$ $(0.20 \mathrm{~g}, 0.37 \mathrm{mmol}), \mathrm{Ag}_{2} \mathrm{O}(0.35 \mathrm{~g}, 1.49 \mathrm{mmol})$ and $\mathrm{KCl}(0.28 \mathrm{~g}$, $3.73 \mathrm{mmol})$ and $\left[\mathrm{Cp}^{*} \mathrm{IrCl}_{2}\right]_{2}(0.14 \mathrm{~g}, 0.18 \mathrm{mmol})$. Purification by column chromatography $\left(\mathrm{SiO}_{2} ; \mathrm{CH}_{2} \mathrm{Cl}_{2}\right.$ then $\mathrm{CH}_{2} \mathrm{Cl}_{2} /$ acetone, 2:1) yielded complex $\mathbf{1 0}$ as a pale yellow solid (113 mg, 39\%).

${ }^{1} \mathrm{H}$ NMR $\left(\mathrm{CD}_{3} \mathrm{CN}, 400 \mathrm{MHz}\right): \delta 7.50\left(\mathrm{tt}, 1 \mathrm{H},{ }^{3} J_{\mathrm{HH}}=7.5 \mathrm{~Hz}\right.$, $\left.{ }^{4} J_{\mathrm{HH}}=1.2 \mathrm{~Hz}, \mathrm{H}_{\mathrm{Ph}}\right), 7.37\left(\mathrm{dd}, 1 \mathrm{H},{ }^{3} J_{\mathrm{HH}}=7.8 \mathrm{~Hz},{ }^{4} J_{\mathrm{HH}}=1.2 \mathrm{~Hz}\right.$, $\left.\mathrm{H}_{\mathrm{Ph}-\mathrm{Ir}}\right)$, 7.33-7.28 (m, 2H, $\left.\mathrm{H}_{\mathrm{Ph}}\right), 6.85-6.80\left(\mathrm{~m}, 1 \mathrm{H}, \mathrm{H}_{\mathrm{Ph}-\mathrm{Ir}}\right)$, 6.70-6.67 (m, 2H, $\left.\mathrm{H}_{\mathrm{Ph}}\right), 6.51\left(\mathrm{dd}, 1 \mathrm{H},{ }^{3} J_{\mathrm{HH}}=7.7 \mathrm{~Hz},{ }^{4} J_{\mathrm{HH}}=1.1\right.$ $\mathrm{Hz}, \mathrm{H}_{\mathrm{Ph}-\mathrm{Ir}}$ ), 6.46-6.41 (m, 1H, $\mathrm{H}_{\mathrm{Ph}-\mathrm{Ir}}$ ), 5.12 (d, $1 \mathrm{H},{ }^{2} J_{\mathrm{HH}}=14.7$ 
$\left.\mathrm{Hz}, \mathrm{OCH}_{2}\right), 5.11,4.90\left(2 \times \mathrm{d}, 1 \mathrm{H},{ }^{2} J_{\mathrm{HH}}=14.9 \mathrm{~Hz}, \mathrm{OCH}_{2}\right), 4.82$ $\left(\mathrm{d}, 1 \mathrm{H},{ }^{2} \mathrm{~J}_{\mathrm{HH}}=14.7 \mathrm{~Hz}, \mathrm{OCH}_{2}\right), 4.09,3.95\left(2 \times \mathrm{s}, 3 \mathrm{H}, \mathrm{NCH}_{3}\right)$, $1.81\left(\mathrm{~s}, 15 \mathrm{H}, \mathrm{Cp}-\mathrm{CH}_{3}\right) .{ }^{13} \mathrm{C}\left\{{ }^{1} \mathrm{H}\right\}$ NMR $\left(\mathrm{CD}_{3} \mathrm{CN}, 100 \mathrm{MHz}\right): \delta$ $149.0\left(\mathrm{C}_{\text {trz }}\right), 148.8\left(\mathrm{C}_{\text {trz }}-\mathrm{Ir}\right), 143.9\left(\mathrm{C}_{\mathrm{Ph}-\mathrm{Ir}}\right), 143.1\left(\mathrm{C}_{\mathrm{trz}}\right), 141\left(\mathrm{C}_{\mathrm{trz}^{-}}\right.$ Ir), $140.7\left(\mathrm{C}_{\mathrm{Ph}}\right), 139.5,138.6\left(2 \times \mathrm{C}_{\mathrm{Ph}-\mathrm{Ir}}\right), 130.7\left(\mathrm{C}_{\mathrm{Ph}}\right), 129.9$ $\left(\mathrm{C}_{\mathrm{Ph}}\right), 128.4\left(\mathrm{C}_{\mathrm{Ph}-\mathrm{Ir}}\right), 126.7\left(\mathrm{C}_{\mathrm{Ph}}\right), 121.9,113.5\left(2 \times \mathrm{C}_{\mathrm{Ph}-\mathrm{Ir}}\right), 93.9$ $\left(\mathrm{C}_{\mathrm{Cp}}\right), 65.2,64.3\left(2 \times \mathrm{OCH}_{2}\right), 37.5,37.3\left(2 \times \mathrm{NCH}_{3}\right), 10.3(\mathrm{Cp}-$ $\left.\mathrm{CH}_{3}\right)$. ESI-MS $(\mathrm{m} / \mathrm{z}):$ 687.2411, calcd for $\left[\mathrm{C}_{30} \mathrm{H}_{34} \mathrm{~N}_{6} \mathrm{OIr}\right]^{+}$ 687.2424. Anal calcd for $\mathrm{C}_{30} \mathrm{H}_{34} \mathrm{BF}_{4} \mathrm{~N}_{6} \mathrm{OIr}$ (773.65): C, 46.57; H, 4.43 ; N, 10.86\%. Found: C, 46.15; H, 4.31; N, 10.60\%.

Synthesis of 13. Triazolium iodide $5 \mathbf{b}(\mathrm{I}) \quad(180 \mathrm{mg}$, $0.293 \mathrm{mmol}$ ) and $\mathrm{KO} t \mathrm{Bu}(55 \mathrm{mg}, 0.49 \mathrm{mmol}$ ) were suspended in dry, degassed MeCN (5 mL). The mixture was stirred at room temperature for 10 minutes. To the pink suspension, $\mathrm{RhCl}_{3} \cdot 3 \mathrm{H}_{2} \mathrm{O}(26 \mathrm{mg}, 0.098 \mathrm{mmol})$ was added and the mixture was heated to reflux for $16 \mathrm{~h}$. After cooling to room temperature, the mixture was filtered in air through Celite, and all volaties were evaporated. The residue was purified by column chromatography $\left(\mathrm{SiO}_{2} ; \mathrm{CH}_{2} \mathrm{Cl}_{2}\right.$ then $\mathrm{NaI}, \mathrm{CH}_{2} \mathrm{Cl}_{2}$ /acetone, $1: 1$ ), which afforded complex 13 as a pale yellow solid (52 mg, $56 \%$ ). Crystals suitable for X-ray diffraction studies were obtained by layering a $\mathrm{CH}_{2} \mathrm{Cl}_{2} / \mathrm{MeCN}(2: 1)$ solution with $\mathrm{Et}_{2} \mathrm{O}$.

${ }^{1} \mathrm{H}$ NMR ( $\left.\mathrm{CD}_{3} \mathrm{CN}, 400 \mathrm{MHz}\right): \delta 7.23\left(\mathrm{t}, 2 \mathrm{H},{ }^{3} J_{\mathrm{HH}}=7.5 \mathrm{~Hz}\right.$, $\left.\mathrm{H}_{\mathrm{Ph}}\right), 6.92\left(\mathrm{t}, 4 \mathrm{H},{ }^{3} J_{\mathrm{HH}}=7.5 \mathrm{~Hz}, \mathrm{H}_{\mathrm{Ph}}\right), 6.75\left(\mathrm{~d}, 2 \mathrm{H},{ }^{3} J_{\mathrm{HH}}=7.6\right.$ $\left.\mathrm{Hz}, \mathrm{H}_{\mathrm{Ph}-\mathrm{Rh}}\right), 6.57,6.45\left(2 \times \mathrm{t}, 2 \mathrm{H},{ }^{3} J_{\mathrm{HH}}=7.6 \mathrm{~Hz}, \mathrm{H}_{\mathrm{Ph}-\mathrm{Rh}}\right), 6.25$ (br, $4 \mathrm{H}, \mathrm{H}_{\mathrm{Ph}}$ ), 6.08 (d, 2H, ${ }^{3} J_{\mathrm{HH}}=7.6 \mathrm{~Hz}, \mathrm{H}_{\mathrm{Ph}-\mathrm{Rh}}$ ), 4.15, 4.03 $\left(2 \times \mathrm{s}, 6 \mathrm{H}, \mathrm{H}_{\mathrm{H}}\right), 3.06-2.97,2.94-2.87,2.61-2.54,2.48-2.38(4 \times$ $\left.\mathrm{m}, 2 \mathrm{H}, \mathrm{C}_{\text {trz }} \mathrm{CH}_{2}\right), 2.12-2.04\left(\mathrm{~m}, 4 \mathrm{H}, \mathrm{C}_{\mathrm{trz}} \mathrm{CH}_{2} \mathrm{CH}_{2}\right) .{ }^{13} \mathrm{C}\left\{{ }^{1} \mathrm{H}\right\} \mathrm{NMR}$ $\left(\mathrm{CD}_{3} \mathrm{CN}, 100 \mathrm{MHz}\right): \delta 176.2\left({ }^{1} J_{\mathrm{CRh}}=34.3 \mathrm{~Hz}, \mathrm{C}_{\mathrm{trz}}-\mathrm{Rh}\right), 171.3$ $\left({ }^{1} J_{\mathrm{CRh}}=30.2 \mathrm{~Hz}, \mathrm{C}_{\mathrm{trz}}-\mathrm{Rh}\right), 164.9\left({ }^{1} J_{\mathrm{CRh}}=25.7 \mathrm{~Hz}, \mathrm{C}_{\mathrm{Ph}}-\mathrm{Rh}\right)$, $146.7\left(\mathrm{C}_{\mathrm{Ph}-\mathrm{Rh}}\right), 145.5\left(\mathrm{C}_{\text {trz }}\right), 143.9\left(\mathrm{C}_{\text {trz }}\right), 139.9\left(\mathrm{C}_{\mathrm{Ph}}\right), 137.1$ $\left(\mathrm{C}_{\mathrm{Ph}-\mathrm{Rh}}\right), 129.2\left(\mathrm{C}_{\mathrm{Ph}}\right), 128.8\left(\mathrm{C}_{\mathrm{Ph}}\right), 126.7\left(\mathrm{C}_{\mathrm{Ph}-\mathrm{Rh}}\right), 126.2\left(\mathrm{C}_{\mathrm{Ph}}\right)$, 121.3, $115.0\left(2 \times \mathrm{C}_{\mathrm{Ph}-\mathrm{Rh}}\right), 36.8,36.5\left(2 \times \mathrm{NCH}_{3}\right), 26.2$ $\left(\mathrm{CCH}_{2} \mathrm{CH}_{2}\right), 22.6,21.3\left(2 \times \mathrm{C}_{\mathrm{trz}} \mathrm{CH}_{2}\right)$. ESI-MS $(\mathrm{m} / \mathrm{z}): 817.2750$, calcd for $\left[\mathrm{C}_{42} \mathrm{H}_{42} \mathrm{~N}_{12} \mathrm{Rh}\right]^{+}$817.2710. Anal calcd for $\mathrm{C}_{42} \mathrm{H}_{42} \mathrm{IN}_{12} \mathrm{Rh}(944.67) \times 0.75 \mathrm{CH}_{2} \mathrm{Cl}_{2}: \mathrm{C}, 50.92 ; \mathrm{H}, 4.35 ; \mathrm{N}$, $16.67 \%$. Found: C, 50.95; H, 4.28; N, 16.37\%.

Synthesis of 14. Following the same procedure as for the synthesis of 13, the triazolium salt $5 \mathbf{b}(\mathrm{I})(125 \mathrm{mg}, 0.203 \mathrm{mmol})$ and $\mathrm{KO} t \mathrm{Bu}(38 \mathrm{mg}, 0.339 \mathrm{mmol})$ and $\mathrm{IrCl}_{3} \cdot 3 \mathrm{H}_{2} \mathrm{O}(24 \mathrm{mg}$, $0.068 \mathrm{mmol}$ ) yielded crude complex 14, which was purified by column chromatography $\left(\mathrm{SiO}_{2} ; \mathrm{CH}_{2} \mathrm{Cl}_{2}\right.$ then $\mathrm{CH}_{2} \mathrm{Cl}_{2}$ /acetone, $1: 1)$ to give the title complex as a pale yellow solid (12 mg, $17 \%)$. Complex 14 decomposes upon extended time in solution. Because of this behaviour and due to the low yield and quantity, we did not succeed in purifying the compound to analytical purity (see also ESI $\dagger$ ).

${ }^{1} \mathrm{H}$ NMR (CD $\left.3 \mathrm{CN}, 400 \mathrm{MHz}\right): \delta 7.22\left(\mathrm{tt}, 2 \mathrm{H},{ }^{3} J_{\mathrm{HH}}=7.5 \mathrm{~Hz}\right.$, $\left.{ }^{4} J_{\mathrm{HH}}=1.1 \mathrm{~Hz}, \mathrm{H}_{\mathrm{Ph}}\right), 6.90\left(\mathrm{br}, 4 \mathrm{H}, \mathrm{H}_{\mathrm{Ph}}\right), 6.72\left(\mathrm{dd}, 2 \mathrm{H},{ }^{3} J_{\mathrm{HH}}=7.7\right.$ $\left.\mathrm{Hz},{ }^{4} J_{\mathrm{HH}}=1.1 \mathrm{~Hz}, \mathrm{H}_{\mathrm{Ph}-\mathrm{Ir}}\right), 6.55\left(\mathrm{~m}, 2 \mathrm{H}, \mathrm{H}_{\mathrm{Ph}-\mathrm{Ir}}\right), 6.42(\mathrm{td}, 2 \mathrm{H}$, $\left.{ }^{3} J_{\mathrm{HH}}=7.3 \mathrm{~Hz},{ }^{4} J_{\mathrm{HH}}=1.3 \mathrm{~Hz}, \mathrm{H}_{\mathrm{Ph}-\mathrm{Ir}}\right), 6.25\left(\mathrm{br}, 4 \mathrm{H}, \mathrm{H}_{\mathrm{Ph}}\right), 6.07$ $\left(\mathrm{dd}, 2 \mathrm{H},{ }^{3} \mathrm{~J}_{\mathrm{HH}}=7.3 \mathrm{~Hz},{ }^{4} J_{\mathrm{HH}}=1.1 \mathrm{~Hz}, \mathrm{H}_{\mathrm{Ph}-\mathrm{Ir}}\right), 4.15,4.03(2 \times \mathrm{s}$, $6 \mathrm{H}, \mathrm{NCH}_{3}$ ), 3.05-2.87 (m, 4H, $\mathrm{C}_{\text {trz }} \mathrm{CH}_{2}$ ), 2.67-2.60, 2.46-2.36 $\left(2 \times \mathrm{m}, 2 \mathrm{H}, \mathrm{C}_{\mathrm{trz}} \mathrm{CH}_{2}\right), 2.11-2.01\left(\mathrm{~m}, 4 \mathrm{H}, \mathrm{CCH}_{2} \mathrm{CH}_{2}\right) .{ }^{13} \mathrm{C}\left\{{ }^{1} \mathrm{H}\right\}$ NMR ( $\left.\mathrm{CD}_{3} \mathrm{CN}, 100 \mathrm{MHz}\right): \delta 158.9\left(\mathrm{C}_{\mathrm{trz}}-\mathrm{Ir}\right), 152.4\left(\mathrm{C}_{\mathrm{trz}}-\mathrm{Ir}\right), 147.9$ $\left(\mathrm{C}_{\mathrm{Ph}}-\mathrm{Ir}\right), 146.9\left(\mathrm{C}_{\mathrm{trz}}\right), 146.7\left(\mathrm{C}_{\mathrm{Ph}-\mathrm{Ir}}\right), 143.3\left(\mathrm{C}_{\mathrm{trz}}\right), 139.9\left(\mathrm{C}_{\mathrm{Ph}}\right)$,
$136.6\left(\mathrm{C}_{\mathrm{Ph}-\mathrm{Ir}}\right), 129.1\left(\mathrm{C}_{\mathrm{Ph}}\right), 128.6\left(\mathrm{C}_{\mathrm{Ph}}\right), 127.3,120.7,115.1(3 \times$ $\left.\mathrm{C}_{\mathrm{Ph}-\mathrm{Ir}}\right), 36.9,36.5\left(2 \times \mathrm{NCH}_{3}\right), 25.8\left(\mathrm{CCH}_{2} \mathrm{CH}_{2}\right), 22.8,21.1(2 \times$ $\mathrm{C}_{\text {trz }} \mathrm{CH}_{2}$ ), one $\mathrm{C}_{\mathrm{Ph}}$ not resolved. ESI-MS $(\mathrm{m} / \mathrm{z})$ : 907.3322, calcd for $\left[\mathrm{C}_{42} \mathrm{H}_{42} \mathrm{~N}_{12} \mathrm{Ir}\right]^{+}$907.3285.

\section{Crystal structure determinations}

Crystal data for 7-9, and $\mathbf{1 3}$ were collected using a Rigaku (former Agilent Technologies) Oxford Diffraction SuperNova A diffractometer fitted with an Atlas detector and using monochromated Mo-K $\mathrm{K}_{\alpha}$ radiation $(0.71073 \AA)$ (7-9) or $\mathrm{Cu}-\mathrm{K}_{\alpha}$ (1.54184 ̊) (13). A complete dataset was collected, assuming that the Friedel pairs are not equivalent. The structures were solved by direct methods using SHELXS-97 and refined by fullmatrix least squares fitting on $F^{2}$ for all data using SHELXL-97. ${ }^{33}$ Hydrogen atoms were added at calculated positions and refined by using a riding model. Anisotropic thermal displacement parameters were used for all non-disordered nonhydrogen atoms. The solvent in $\mathbf{1 3}$ could not be modelled in terms of atomic sites. The SQUEEZE option as incorporated in PLATON ${ }^{34}$ was used to compensate for the spread electron density. The B-F bonds of the tetrafluoroborate anion in 7 were restrained to be equal using SADI. Further crystallographic details are compiled in Tables S1-S3. $\dagger$ Crystallographic data (excluding structure factors) for all three complexes have been deposited with the Cambridge Crystallographic Data Centre as supplementary publication no. CCDC 1477830 (7), 1477829 (8), 1477828 (9) and 1477827 (13).

\section{Acknowledgements}

This work has been financially supported by a NUI Traveling Scheme (K. F.), by the European Research Council (CoG 615653) and Science Foundation Ireland (RFP/2010/CHS2844).

\section{References}

1 (a) F. E. Hahn and M. C. Jahnke, Angew. Chem., Int. Ed., 2008, 47, 3122; (b) A. J. Arduengo and G. Bertrand, Chem. Rev., 2009, 109, 3209; (c) D. Bourissou, O. Guerret, F. P. Gabbaï and G. Bertrand, Chem. Rev., 2000, 100, 39.

2 (a) A. Kascatan-Nebioglu, M. J. Panzner, C. A. Tessier, C. L. Cannon and W. J. Youngs, Coord. Chem. Rev., 2007, 251, 884; (b) M.-L. Teyssot, A.-S. Jarrousse, M. Manin, A. Chevry, S. Roche, F. Norre, C. Beaudoin, L. Morel, D. Boyer, R. Mahiou and A. Gautier, Dalton Trans., 2009, 6894; (c) L. Mercs and M. Albrecht, Chem. Soc. Rev., 2010, 39, 1903; (d) R. Visbal and M. C. Gimeno, Chem. Soc. Rev., 2014, 43, 3551.

3 (a) W. A. Herrmann, Angew. Chem., Int. Ed., 2002, 41, 1290; (b) N-Heterocyclic Carbenes in Transition Metal Catalysis, in Topics in Organometallic Chemistry, ed. F. Glorius, Springer, Berlin, 2007; (c) S. Díez-González, N. Marion and S. P. Nolan, Chem. Rev., 2009, 109, 3612; (d) M. Poyatos, J. A. Mata and E. Peris, Chem. Rev., 2009, 109, 3677; 
(e) C. M. Crudden and D. P. Allen, Coord. Chem. Rev., 2004, 248, 2247; $(f)$ R. H. Crabtree, Coord. Chem. Rev., 2007, 251, 595; $(g)$ N-Heterocyclic Carbenes: from Laboratory Curiosities to Efficient Synthetic Tools, ed. S. Díez-González, RSC Publishing, Cambridge, 2011; (h) N-Heterocyclic Carbenes in Transition Metal Catalysis and Organocatalysis, ed. C. S. J. Cazin, Springer, Berlin, 2011.

4 (a) M. C. Perry and K. Burgess, Tetrahedron: Asymmetry, 2003, 14, 951; (b) J. J. Van Veldhuizen, J. E. Campbell, R. E. Giudici and A. H. Hoveyda, J. Am. Chem. Soc., 2005, 127, 6877; (c) E. P. Kündig, T. M. Seidel, Y. X. Jia and G. Bernardinelli, Angew. Chem., Int. Ed., 2007, 46, 8484.

5 J. Vignolle, X. Cattoën and D. Bourissou, Chem. Rev., 2009, 109, 3333.

6 (a) K. Ofele, E. Tosh, C. Taubmann and W. A. Herrmann, Chem. Rev., 2009, 109, 3408; (b) O. Schuster, L. Yang, H. G. Raubenheimer and M. Albrecht, Chem. Rev., 2009, 109, 3445; (c) M. Melaimi, M. Soleilhavoup and G. Bertrand, Angew. Chem., Int. Ed., 2010, 49, 8810.

7 See for examples: (a) A. T. Normand and K. J. Cavell, Eur. J. Inorg. Chem., 2008, 2781; (b) E. Peris and R. H. Crabtree, Coord. Chem. Rev., 2004, 248, 2239; (c) J. F. Lefebvre, M. Lo, D. Leclercq and S. Richeter, Chem. Commun., 2011, 47, 2976; (d) K. Farrell and M. Albrecht, in The Privileged Pincer-Metal Platform: Coordination Chemistry \& Applications, Topics in Organometallic Chemistry, ed. G. van Koten and R. A. Gossage, Springer, Berlin, 2016, p. 45.

8 (a) P. Mathew, A. Neels and M. Albrecht, J. Am. Chem. Soc., 2008, 130, 13534; (b) G. Guisado-Barrios, J. Bouffard, B. Donnadieu and G. Bertrand, Angew. Chem., Int. Ed., 2010, 49, 4759; (c) J. D. Crowley, A. Lee and K. J. Kilpin, Aust. J. Chem., 2011, 64, 1118; (d) K. F. Donnelly, A. Petronilho and M. Albrecht, Chem. Commun., 2013, 49, 1145; (e) B. Schulze and U. S. Schubert, Chem. Soc. Rev., 2014, 43, 2522.

9 For selected and recent examples, see: (a) J. Bouffard, B. K. Keitz, R. Tonner, V. Lavallo, G. Guisado-Barrios, G. Frenking, R. H. Grubbs and G. Bertrand, Organometallics, 2011, 30, 2617; (b) B. K. Keitz, J. Bouffard, G. Bertrand and R. H. Grubbs, J. Am. Chem. Soc., 2011, 133, 8498; (c) E. C. Keske, O. V. Zenkina, R. Wang and C. M. Crudden, Organometallics, 2012, 31, 6215; (d) D. Canseco-Gonzalez, A. Petronilho, H. Müller-Bunz, K. Ohmatsu, T. Ooi and M. Albrecht, J. Am. Chem. Soc., 2013, 135, 13193; (e) J. R. Wright, P. C. Young, N. T. Lucas, A.-L. Lee and J. D. Crowley, Organometallics, 2013, 32, 7065; (f) I. Corbucci, A. Petronilho, H. Müller-Bunz, L. Rocchigiani, M. Albrecht and A. Macchioni, ACS Catal., 2015, 5, 2714; $(g)$ R. Heath, H. Müller-Bunz and M. Albrecht, Chem. Commun., 2015, 51, 8699; (h) S. Hohloch, S. Kaiser, F. L. Duecker, A. Bolje, R. Maity, J. Košmrlj and B. Sarkar, Dalton Trans., 2015, 44, 686; (i) M. Valencia, H. Müller-Bunz, R. A. Gossage and M. Albrecht, Chem. Commun., 2016, 52, 3344.

10 (a) D. G. Brown, N. Sanguantrakun, B. Schulze, U. S. Schubert and C. P. Berlinguette, J. Am. Chem. Soc.,
2012, 134, 12354; (b) V. Leigh, W. Ghattas, R. Lalrempuia, H. Müller-Bunz, M. T. Pryce and M. Albrecht, Inorg. Chem., 2013, 52, 5395; (c) D. G. Brown, P. A. Schauer, J. BorauGarcia, B. R. Fancy and C. P. Berlinguette, J. Am. Chem. Soc., 2013, 135, 1692.

11 (a) According to the IUPAC Golden Book, mesoionic compounds are "Dipolar five- (possibly six-) membered heterocyclic compounds in which both the negative and the positive charge are delocalized, for which a totally covalent structure cannot be written, and which cannot be represented satisfactorily by any one polar structure. The formal positive charge is associated with the ring atoms, and the formal negative charge is associated with ring atoms or an exocyclic nitrogen or chalcogen atom. Mesoionic compounds are a subclass of betains." IUPAC. Compendium of Chemical Terminology, 2nd ed. (the "Gold Book") compiled by McNaught AD and Wilkinson A. Blackwell Oxford, UK: Scientific Publications; 1997. See also: (b) S. Araki, Y. Wanibe, F. Uno, A. Morikawa, K. Yamamoto, K. Chiba and Y. Butsugan, Chem. Ber., 1993, 12, 1149.

12 (a) R. H. Crabtree, Coord. Chem. Rev., 2013, 257, 755; (b) M. Albrecht, Adv. Organomet. Chem., 2014, 62, 111.

13 (a) R. Huisgen, Angew. Chem., Int. Ed., 1963, 2, 565; (b) H. C. Kolb, M. G. Finn and K. B. Sharpless, Angew. Chem., Int. Ed., 2001, 40, 2004; (c) V. V. Rostovtsev, L. G. Green, V. V. Fokin and K. B. Sharpless, Angew. Chem., Int. Ed., 2002, 41, 2596; (d) F. Himo, T. Lovell, R. Hilgraf, V. V. Rostovtsev, L. Noodleman, K. B. Sharpless and V. V. Fokin, J. Am. Chem. Soc., 2005, 127, 210.

14 (a) V. D. Bock, H. Hiemstra and J. H. Van Maarseveen, Eur. J. Org. Chem., 2006, 51; (b) M. Meldal and C. W. Tornøe, Chem. Rev., 2008, 108, 2952; (c) J. E. Hein and V. V. Fokin, Chem. Soc. Rev., 2010, 39, 1302.

15 E. C. Keske, O. V. Zenkina, R. Wang and C. M. Crudden, Organometallics, 2012, 31, 456.

16 (a) B. Schulze, D. Escudero, C. Friebe, R. Siebert, H. Goerls, U. Koehn, E. Altuntas, A. Baumgaertel, M. D. Hager, A. Winter, B. Dietzek, J. Popp, L. Gonzalez and U. S. Schubert, Chem. - Eur. J., 2011, 17, 5494; (b) S. Sinn, B. Schulze, C. Friebe, D. G. Brown, M. Jäger, E. Altuntaş, J. Kübel, O. Guntner, C. P. Berlinguette, B. Dietzek and U. S. Schubert, Inorg. Chem., 2014, 53, 2083.

17 D. I. Bezuidenhout, G. Kleinhans, G. Guisado-Barrios, D. C. Liles, G. Ung and G. Bertrand, Chem. Commun., 2014, 50, 2431.

18 M. T. Zamora, M. J. Ferguson and M. Cowie, Organometallics, 2012, 31, 5384 .

19 G. Guisado-Barrios, J. Bouffard, B. Donnadieu and G. Bertrand, Organometallics, 2011, 30, 6017.

20 S. Hohloch, L. Suntrup and B. Sarkar, Organometallics, 2013, 32, 7376.

21 J. Cai, X. Yang, K. Arumugam, C. W. Bielawski and J. L. Sessler, Organometallics, 2011, 30, 5033.

22 A. Petronilho, J. A. Woods, S. Bernhard and M. Albrecht, Eur. J. Inorg. Chem., 2014, 708. 
23 (a) A. Krüger, L. J. L. Häller, H. Müller-Bunz, O. Serada, A. Neels, S. A. Macgregor and M. Albrecht, Dalton Trans., 2011, 40, 9911; (b) A. Krüger, A. Neels and M. Albrecht, Chem. Commun., 2010, 46, 315; (c) J. A. Cabeza, M. Damonte, P. Garcia-Alvarez and E. Perez-Carreno, Chem. Commun., 2013, 49, 2813.

24 (a) K. M. Mullen, J. Mercurio, C. J. Serpell and P. D. Beer, Angew. Chem., Int. Ed., 2009, 48, 4781; (b) J. Dupont, P. A. Z. Suarez, R. F. De Souza, R. A. Burrow and J.-P. Kintzinger, Chem. - Eur. J., 2000, 6, 2377.

25 (a) J. C. Y. Lin, R. T. W. Huang, C. S. Lee, A. Bhattacharyya, W. S. Hwang and I. J. B. Lin, Chem. Rev., 2009, 109, 3561; (b) J. C. Garrison and W. J. Youngs, Chem. Rev., 2005, 105, 3978.

26 (a) T. Nakamura, T. Terashima, K. Ogata and S.-I. Fukuzawa, Org. Lett., 2011, 13, 620; (b) S. Hohloch, L. Hettmanczyk and B. Sarkar, Eur. J. Inorg. Chem., 2014, 3164.

27 M. Iglesias, D. J. Beetstra, J. C. Knight, L.-L. Ooi, A. Stasch, S. Coles, L. Male, M. B. Hursthouse, K. J. Cavell, A. Dervisi and I. A. Fallis, Organometallics, 2008, 27, 3279.

28 (a) H.-L. Su, L. M. Pérez, S.-J. Lee, J. H. Reibenspies, H. S. Bazzi and D. E. Bergbreiter, Organometallics, 2012, 31, 4063-4071; (b) E. Caytan and S. Roland, Organometallics, 2014, 33, 2115-2118.

29 For a related system with imidazol-2-ylidene ligands and smaller bite angles, see: J. A. Mata, A. R. Chianese, J. R. Miecznikowski, M. Poyatos, E. Peris, J. W. Faller and R. H. Crabtree, Organometallics, 2004, 23, 1253.
30 (a) R. Lalrempuia, N. D. McDaniel, H. Mueller-Bunz, S. Bernhard and M. Albrecht, Angew. Chem., Int. Ed., 2010, 49, 9765; (b) A. Poulain, D. Canseco-Gonzalez, R. Hynes-Roche, H. Müller-Bunz, O. Schuster, H. Stoeckli-Evans, A. Neels and M. Albrecht, Organometallics, 2011, 30, 1021; (c) R. Saravanakumar, V. Ramkumar and S. Sankararaman, Organometallics, 2011, 30, 1689; (d) L. Bernet, R. Lalrempuia, W. Ghattas, H. Mueller-Bunz, L. Vigara, A. Llobet and M. Albrecht, Chem. Commun., 2011, 47, 8058; (e) A. Petronilho, M. Rahman, J. A. Woods, H. Al-Sayyed, H. Müller-Bunz, J. M. Don MacElroy, S. Bernhard and M. Albrecht, Dalton Trans., 2012, 41, 13074; $(f)$ K. F. Donnelly, R. Lalrempuia, H. Müller-Bunz and M. Albrecht, Organometallics, 2012, 31, 8414; $(\mathrm{g}) \mathrm{K}$. Ogata, S. Inomata and S. Fukuzawa, Dalton Trans., 2013, 42, 2362.

31 W. A. Herrmann and M. G. Gardiner, Organometallics, 1999, 18, 4082.

32 Further attempts to characterize complex 15 included trapping of this species with $\mathrm{PPh}_{3}$. The appearance of a doublet in the ${ }^{31} \mathrm{P}$ NMR spectrum $\left(\delta_{\mathrm{P}} 15.2,{ }^{1} J_{\mathrm{PRh}}=\right.$ $92 \mathrm{~Hz}$ ) as well as a MS signal at confirmed phosphine coordination to rhodium, however, crystallization efforts to obtain structural information have been unsuccessful.

33 G. M. Sheldrick, Acta Crystallogr., Sect. A: Fundam. Crystallogr., 2008, 64, 112.

34 A. L. Spek, J. Appl. Crystallogr., 2003, 36, 7. 